\title{
The Podobny Texts and Chants of the Supraśl Irmologion of 1601
}

\author{
BY
}

\section{H. PICHURA}

Considerable research has been carried out during the last hundred years in the field of East Slavonic liturgical music. Most authors, however, have limited their activities to the study of the chants of the Russian Orthodox Church. Relatively little attention has been paid so far to the Byelorussian and Ukrainian liturgical heritage. Seen in the perspective of the Russian musical tradition, Byelorussia and the Ukraine were merely intermediate zones, through which West European influences penetrated to reach Russia in the 17th and 18th centuries. Musicologists and musical historians such as D. Razumovskij, S. Smolenskij, V. Metallov, A. Preobraženskij, N. Findejzen and J. Gardner gave some consideration in their works to the ecclesiastical music of what they generally referred to as Jugozapadnaja Ruś (south-western Ruś), but they dealt with it only insofar as it played a relevant role in the development of Church chants in Russia. They displayed little interest in following the evolution of any distinctive and coherent musical tradition in Byelorussia or the Ukraine. ${ }^{1}$

This was perhaps a not unnatural tendency. The culture of the Western borderlands of the Russian Empire had, from relatively early times, displayed many elements which were alien to the Russian traditions, and which rendered it unattractive, and even suspect, to the Byzantine purists of the Panslavist movement. Compared to the elegant, well-mannered chants of the Russian Synodal cycle which had appeared in 1772, the freer, more elaborate melodies of the 'Jugozapadnyj' or 'zapadno-russkij' Irmologia seemed overdecorative and baroque. Moreover, their liturgical purity was questionable, since they had evolved in lands subject to the Catholic Grand Dukes of Lithuania, and had been used in the Greek-Catholic or Uniate Church, an institution viewed with the utmost suspicion and resentment by the Russian Orthodox establishment. ${ }^{2}$

In the field of Ukrainian Church music, valuable work was done in the 19th century by authors such as J. de Castro and D. Malaškin, who published and commented on the liturgical chants of Galicia and the Kievo-Pečerskaja Lavra. ${ }^{3}$ Later musicologists such as F. Steško, B. Kudryk and E. Spikula did much to promote an interest in the Ukrainian musical heritage.

On the other hand, the Byelorussian tradition remained shrouded in obscurity, with the exception of one or two comments of considerable value in the works of Razumovskij and Preobraženskij. ${ }^{4}$ The first 
serious attempt to break into this new field was made by Archpriest I. Voznesenskij, who in the last decade of the 19th century published an extensive study of the chants of the 'Graeco-Russian' Church in six parts. The second part of his work entitled Osmoglasnyje rospevy trech poslednich vekov pravoslavnoj russkoj cerkvi deals with the non-Russian chants - Kievskij rospev, Bolgarskij rospev and Grečeskij rospev - which were received into the Russian tradition in the 17th century. All three of these cycles penetrated into Russia to some extent through Byelorussia, and as such they are relevant also to the history of Byelorussian Church music. In the third part of his work, however, Voznesenskij touches more directly on the subject of ecclesiastical chants in Byelorussia and the Ukraine under the heading Cerkovnoje penije jugozapadnoj Rusi po Irmologam 17 i 18 vekov (Moscow, 1898).

Although Voznesenskij seems to have had access to a good number of Byelorussian and Ukrainian Irmologia, his findings are often erratic, and his conclusions occasionally verge on the naive. ${ }^{5}$ Nevertheless his study is a good point de départ, and a useful guide to the student of Byelorussian Church music.

Apart from one or two excellent monographs by A. Preobraženskij which deal indirectly with Byelorussian ecclesiastical traditions, little else was done in the field during the first part of the present century, largely as a result of the lack of interest which Soviet musicologists have tended to show in the subject. In 1927, in the Ukrainian journal Muzyka, there appeared a valuable study on the Supraśl Irmologion, one of the most interesting collections of Byelorussian Church chants compiled by the monk Bohdan Anisimovič of Pinsk in 1601.6 Although this collection, which was first mentioned by Preobraženskij in 1910, is a basic work in the evolution of Byelorussian music in general, its existence is still passed over in silence in modern works on the subject.

Mikoła Kulikovič (1892-1968), a composer who in his later years displayed a great interest in the liturgical music of Byelorussia, did make an attempt to provide an outline, but he was severely handicapped through lack of sources at his disposal.

Few old manuscript chant books dating from before the mid-19th century are now to be found in Byelorussian churches, and fewer still have found their way to the West. When the Byelorussian Uniate Church was suppressed in most of Byelorussia in 1839, and in Podlasia in 1874, numerous monastery and church libraries were removed to archives inside Russia.' Further collections were taken from the Western provinces during the 1914-1918 war, and much of what remained was destroyed during the Second World War.

The task of tracking down these collections is a daunting one. Important deposits of Byelorussian musical manuscripts are however to be found in Vilna, Kiev, Warsaw, Leningrad, Cracow and Moscow, and most of these have been adequately catalogued. ${ }^{10}$ It is in these collections in the first place that the student must search for sources. It is not always easy to identify the origin of a chant book, since the 
catalogues almost invariably refer to a manuscript as being: Irmologij notnyj zapadno-russkij, or, even more vaguely, Složenije hirmov cerkovnych, Śpiewnik Ruski, and Pieśni Cerkiewne. Similarly, where a place of origin is entered in the catalogue, it is not always certain whether the collection was actually compiled there, or whether it was merely found in that locality. Considerable caution must therefore be exercised in examining a manuscript before identifying it as an example of Byelorussian Church music. Some chant books may however be ascribed to a specifically Byelorussian source by reason partly of the copyist's own notes and comments, partly through marginal notes added in a later hand, and partly by the intrinsic characteristics of the chants and texts themselves. For example, there can be little doubt that an Irmologion bearing the inscription: 'Сей Ірмолой церкви Жіровіцкой' was in fact compiled in the monastery of Žyrovicy. ${ }^{11}$ On the other hand, a note to the effect that 'Ten Irmolog dany ode mnie do cerkwi Swientey troycy Zakonu Swiętego Bazylego u miescie Wilni na zawsze ma być przy cerkwi przy chorze dnia czwartego miesionca oktobra roku 1734, Daniel Antoniy Swiszczewski', is of little assistance in determining a collection's place of origin. ${ }^{12}$ At the most it may assist in following its vagaries over the years, and possibly in establishing what chants were currently sung in a given area, but little else besides. Thus it is that one not infrequently finds Kievan or Galician chant books turning up in the monastery libraries of Vilna and Supraśl, even as Irmologia noted 'belorusskij spisok' or 'belorusskaja skoropis', are to be found in Galicia and the Transcarpathian Ukraine. ${ }^{13}$

There are in the libraries of Leningrad, Moscow, Kiev and Vilna a large number of Irmologia described simply as 'Zapadno-russkij'. This qualification is not so imprecise, when it is remembered that it is distinguished from 'Jugozapadno-russkij'. The latter term is used to describe manuscripts which originate essentially from the Ukraine, whereas the former, although it may cover collections from Volhynia, and even Galicia, is more often used in relation to Byelorussian works. In the absence of any other indication of the origin of a given manuscript, it is possible sometimes to identify a chant book as Byelorussian by comparing the chants themselves with those of other collections which are of ascertainable origin. This is by no means an entirely satisfactory method, since certain chants are common to both Byelorussian and Ukrainian traditions, whereas others may be restricted to a narrowly defined locality. ${ }^{14}$

Similarities exist also between the form of notation used in the earlier Irmologia, and these are no small assistance in identifying works of Byelorussian origin, though considerable circumspection is called for, and all the other relevant indices must be considered before coming to any firm conclusion.

It is possible to rely to some extent upon the texts of the chants themselves. Prior to the reforms introduced into Russia in 1652 by the Patriarch of Moscow, Nikon, Byelorussians, Ukrainians and Russians made use of a version of the Old Slavonic text known as the 
Iosifskij tekst, though naturally variants existed from region to region. After the so-called Nikonite reforms, which were never accepted in Byelorussia and the Ukraine until the suppression of the Union in 1839 , no confusion is likely. ${ }^{15}$ To provide but one example, the hymn to the Theotokos in the Byzantine liturgy of St. Basil the Great begins with the words 'O Тобъ радуется обрадованная вся тварь'. In the Nikonite or Russian Synodal version this became 'O Тебъ радуется благодатная всякая тварь'. These variants are legion, and are helpful in determining the age and origin of a manuscript, particularly in the case of documents more than 150 years old.

Occasionally one finds in certain Zapadno-russkij collections variants in the Old Slavonic text which indicate that the manuscript was written by a Byelorussian hand. These 'variants' are rather in the nature of copyist's 'slips', and occur when the writer lapses into Byelorussian or sometimes even Polish idiomata. Isolated instances of the influence on the Old Slavonic texts of specifically Byelorussian features such as akańnie and cekańnie occur from time to time: thus irmoloj becomes ermoloj, and even more strikingly jarmoloj; dohmat changes to dahmat and so on. Conversely one finds svety for svjaty, and človek for čelovek.

In contrasting the musical content of the Synodal cycle of Russian Church chants with that of the so-called Zapadno-russkij (mainly Byelorussian) cycle, Voznesenskij expressed the view that the number and variety of the chants in the Russian chant book exceeded those in the Byelorussian and Ukrainian Irmologia. ${ }^{17}$ Whereas it had been found necessary to make special collections of chants from the Obichod, Irmologion, Osmoglasnik and Mineia, no such need had arisen in Byelorussia and the Ukraine, where all these chants were included in a single collection, the Irmologion. There is some truth in this assessment, although in practice Byelorussian Irmologia were often very extensive and comprised a surprising abundance of liturgical chants. Moreover, Byelorussian and Ukrainian church choirs from the 17 th century onwards were much given to singing anthems in four-part harmony, whether in Slavonic, Latin or Polish, paraliturgical hymns (kantyčki), ${ }^{18}$ and motets with organ accompaniment. It was natural that this style of church-singing should to some extent inhibit the development of chants based on strictly liturgical texts and modes.

Among the earlier Byelorussian collections of Church chants it is the Supraśl Irmologion of 1601 which has attracted the most attention, and which is undoubtedly one of the most interesting. The philologist Karskij took note of it as a valuable source of Middle Byelorussian texts, ${ }^{19}$ whereas Preobraženskij stressed its importance in the evolution of East Slav church notation from the znamenny or neumatic to the linear staff system. ${ }^{20}$ Since then, a limited number of articles and monographs have appeared on the subject of the Supraśl Irmologion, although none have examined its form and contents in any great detail. 
From many points of view the Supraśl collection is of outstanding interest. ${ }^{22}$ It was written in the West Byelorussian monastery of the Annunciation, one of the most important spiritual and cultural centres of the nation. ${ }^{23}$ The Irmologion comprises some 700 folios, and is written in a single hand in cursive script. According to the inscription on the title page, it was compiled by a monk of Supraśl, Bohdan Anisimovič, who was a native of Pinsk, in the South Byelorussian palatinate of Brest. The author was more than a mere copyist, and his work was a conscientious attempt to record not only the ancient znamenny chants as then used in Byelorussia, but also a variety of other local, and even foreign chants which had been received into the choral repertoire of his monastery. In recording these, he added short instructions on when such and such a hymn was to be sung, as well as notes on the origin of a given chant, or the circumstances in which it was noted down: 'Цари городскій, глася третей преположен от пъвца патриаршей нарукый..... в раку [1583] се̄н и зъло красный', or 'Сie поем на литуріи велик' Василя Задостойникъ напълу мирского'. ${ }^{24}$

Copyists of Irmologia were not usually so engagingly garrulous. Among the various chants he records, prominence of place is given to the chants of his own monastery (' $И$ сей поем на всенощномъ напълу супрасльского. Сш стих поется ... напълу МС, Сеже есть напълу монастыря супрасльского') ${ }^{25}$ the chants of Mir (Mirski napieł, na provodie Mirskom), the Greek chant (Grečeski rospiev, Hrecki napieł), and the demestvenny chants. ${ }^{26}$

The notation of the Irmologion is of the greatest importance, since it represents the earliest known example of the Western staff notation being used in connexion with East Slavonic liturgical texts. If the exceptionally fine red monochrome miniatures and polychrome decorative blocks in the Supraśl collection were also executed by Anisimovič himself, this talented monk must been a man of many parts. $^{27}$

Structurally the Supraśl Irmologion, and indeed other early Byelorussian manuscript Irmologia in the linear notation lack the coherence and order of later printed versions from L'vov (1700) and Moscow (1772). In the former, texts proper to the Liturgy of St. John Chrysostom such as a Cherubik or a Potirion Sotiriou (both in the Greek language) are intercaled as it were, with little sense of order or convenience, between the Vesper doxology 'Благослови душе моя господа' (f. 192) and the Dogmatiki (f. 198) which belong to the service of the all-night Vigil. In the same way another Cherubik in the Supraśl chant (f. 223) follows a hymn to the Theotokos from the canon of the Liturgy of St. Basil the Great 'О тебе радуется', and precedes a Kinonik or communion hymn 'В памят вечную'. On the other hand all the podobny of the Supraśl Irmologion, as in other Byelorussian Irmologia of the early 17th century, are grouped together in a separate section under the common heading of 'podobny' or 'podobniki', ${ }^{28}$ whereas in later Ukrainian and Russian works, the 
podobny chants are not so grouped, but are classified separately with the stichiry of their respective echoi (htasy) or tone.

The podobny of the Supraśl Irmologion form a separate unit of particular interest in that their preservation is attributed by Bohdan Anisimovič to another copyist 'I.T.'. Indeed, the copyist's note preceding the first podoben of the first tone specifies: 'Напълоу монастыря супрасльского праведно внотование I. T. ${ }^{29}$

Who this original compiler was is not known, and Anisimovič failed to record his full name. He must have been a monk, or at least a pious layman, who was fully familiar with the customs, usages and chants of the Monastery of Supraśl. The date of his death is also unknown, but it is possible that he was no longer living at the time Anisimovic was writing, and that the latter made use of 'I. T.' 's manuscript material. It may be that he was one of the monks who perished in the great plague of 1572, which reduced the number of clerks regular at the Monastery of the Annunciation from 32 to $12^{30}$

The grouping of the podobny into a separate section of the Irmologion was, as has been said, a common feature of early Byelorussian hymnody in the 16th century. Instances of such a grouping of the podobny are to be found in chant books both in the znamenny, and in the later linear notation. Useful comparisons may be drawn with Irmologia which are approximately contemporary, in particular an Irmologion in the znamenny notation dating from the mid-16th century, now in the Biblioteka Narodowa, Warsaw, ${ }^{31}$ and a later version with linear notation closely resembling that of the Supraśl Irmologion, and dating from the first quarter of the 17th century, which is to be found in the Czartoryski Museum in Cracow. ${ }^{32}$ Both these manuscripts have been identified as Byelorussian, and provide valuable means of comparison both from a textual and from a melodic point of view.

The podobny are a system of liturgical chants adapted to one of the minor poetic forms of Byzantine hymnography known as the stichira. ${ }^{33}$ Stichiry were monostrophic hymns which followed the reading of a versicle or stich, generally taken from the psalms, during the Vespers service of the Byzantine Church. These stichiry were sung in accordance with the traditional eight tones (oktoechos, 'октоїх', 'восьмагласые') which, in the Eastern Slav world was based, not on the ancient Greek modes, or on the mediaeval scale system, but on the oriental pattern (maqqam) principle, systematised by St. John Damascene in the 8th century. Each of the eight tones or htasy is made up of a number of these patterns or papieüki, the sum total of which gives to the tone its distinctive musical character. ${ }^{34}$

In the East Slav usage, the tones applied to the various stichiry were by no means uniform. The stichira 'Господи воззвах к Тебе', the text of which is sung to each of the eight tones, generally has a relatively straightforward, unadorned chant. Other stichiry, such as the dahmaty, siedialny and the podobny, were more solemn in character, and called for richer, more ornamented chants.

Any stichiry which had their own individual melodies in one or 
other of the eight tones is described as being 'samopiesno. ${ }^{35}$ Where, however, a text had been set to an existing melody, it was necessary to indicate in the osmahlasnik or oktoechos, the appropriate pattern or podoben to which the stichira was to be sung. For example, in the stichira na stichovnie for Saturday morning in the 2nd tone, the stichira 'Стремленіе смертное' is given as being sung to the podoben 'Егда от древа'. Again the stichiry krestny 'На кресте тя волею нас ради' for Wednesday morning in the 6th tone are noted to be sung to the podoben 'Все отложше'.

The number of podobny found in the Byelorussian Irmologia of the 16th and early 17 th centuries appears to vary considerably, and although some hymns such as 'Небесным чином радование' (1st tone), 'Третий день воскресл еси' (6th tone) and 'O преславное чудо' (8th tone) are relatively commonplace, others such as 'Кто ти спаси ризу раздра' (2nd tone) and 'Кими похвалными вънцы' (8th tone) are infrequently encountered. BN Aks. 2954 has twenty-three podobny in the 8 tones, including several of the more uncommon texts such as 'Кими похвалными вънцы' 'Терпяще мучения кръпок' and 'Иже во едеме рай'. Cz. 2055. I. has twenty-one podobny, and the Supraśl Irmologion has the relatively low number of sixteen. This compares with a total of twenty-six podobny in the L'vov Irmologion of 1700, fifteen in the Prostopenije of the Carpatho-Ukrainians published in 1955, and 13 in the Russian 'Obichod Valaamskogo monastyrja' of 1909. Although by comparison with other collections the number of podobny in the Supraśl Irmologion is modest, the most common texts are included, and provide a comparatively comprehensive body of chant patterns.

\begin{tabular}{|c|c|c|}
\hline $\begin{array}{l}\quad \text { BN Aks. } 2954 \\
\text { lst Tone } \\
\text { Небесных чином } \\
\text { радование } \\
\text { Прехвалении моученици } \\
\text { О дивное чюдо }\end{array}$ & $\begin{array}{l}\text { Supraśl Irm. } \\
\text { Небесных чинов } \\
\text { радование } \\
\text { Прехвалении мученицы } \\
\text { - }\end{array}$ & \begin{tabular}{l} 
Cz. 2055. I. \\
Небесным чином \\
радование \\
Прехвалении мученици \\
\multicolumn{2}{c}{}
\end{tabular} \\
\hline $\begin{array}{l}\text { 2nd Tone } \\
\text { Кими похвалении } \\
\text { Доме ефраитово } \\
\text { Егда ото древа }\end{array}$ & $\begin{array}{l}\text { Доме ефратово } \\
\text { Егда ото древа }\end{array}$ & $\begin{array}{l}\text { Доме ефраифо } \\
\text { Егда ото древа }\end{array}$ \\
\hline $\begin{array}{l}3 r d \text { Tone } \\
\text { Tерпяще моучения } \\
\text { Велия креста твоего }\end{array}$ & $\frac{-}{\text { Велия креста твоего }}$ & Велия креста твоего \\
\hline $\begin{array}{l}\text { 4th Tone } \\
\text { Яко добля во моучени- } \\
\text { цехо } \\
\text { Даль еси знамение } \\
\text { Званныи свыше } \\
\text { Хотъхь слезами }\end{array}$ & $\begin{array}{l}\text { Яко добля во мучени- } \\
\text { цехо } \\
\text { Дал еси знаменіе } \\
\text { Званыи совыше } \\
\text { - }\end{array}$ & $\begin{array}{l}\text { Яко добля во моучени- } \\
\text { цехо } \\
\text { Дал еси знамение } \\
\text { Званныи совыше } \\
\text { Хотех слезами }\end{array}$ \\
\hline
\end{tabular}




\begin{tabular}{|c|c|c|}
\hline $\begin{array}{l}\text { 5th Tone } \\
\text { Радоуися живоносныи } \\
\text { кресте } \\
\text { Преподобене отече }\end{array}$ & $\begin{array}{ll}\text { Радуиися } & \text { живоносныи } \\
\text { кресте } & \\
& -\end{array}$ & $\begin{array}{l}\text { Радоуся живоносныи } \\
\text { кресте } \\
\text { Преподобене отече }\end{array}$ \\
\hline \begin{tabular}{l} 
6th Tone \\
Весе оурование \\
Неначаемая жития \\
Третыи день воскресл \\
\multicolumn{1}{c}{}
\end{tabular} & $\begin{array}{l}\text { Все упование } \\
\text { Третыи день воскресл } \\
\text { Не начаемая жития } \\
\text { Ангелеския предо идуте }\end{array}$ & $\begin{array}{l}\text { Ангелския предо идуте } \\
\text { Третыи день воскресл } \\
\text { Весе упование } \\
\text { Неначаемая жития }\end{array}$ \\
\hline $\begin{array}{l}\text { 7th Tone } \\
\text { Нектому возбраняеми }\end{array}$ & Нектому возбраняеми & Нектому возвраняеми \\
\hline $\begin{array}{l}\text { 8th Tone } \\
\text { Господи аще насоудищи } \\
\text { О преславное чудо } \\
\text { Моученици твои господи } \\
\text { Что вы наречемо святии } \\
\text { Иже во едеме рай }\end{array}$ & $\begin{array}{l}\text { О преславеное чудо } \\
\text { Что вы наречемо святии }\end{array}$ & $\begin{array}{l}\text { О преславленное чудо } \\
\text { Что вас наречемо святии } \\
\text { Кто ти спасе ризу } \\
\text { раздра } \\
\text { Господи аще насудищи } \\
\text { Мученици господи }\end{array}$ \\
\hline
\end{tabular}

The text of the podobny chants of the Supraśl Irmologion is essentially the Old Church Slavonic version commonly known as the Iosifskij or 'unreformed' text. This version prevailed throughout the East Slavonic lands until 1668, when the ecclesiastical authorities of the Russian Empire, at the instigation of Tsar Alexej Michajlovič and the Patriarch of Moscow, Nikon, adopted the textual reforms proposed by the Mezenec Commission. ${ }^{38}$ These reforms were designed to bring the usages of the Russian Orthodox Church into closer line with those of the Greek Church, from which they had diverged somewhat in the course of the Middle Ages. Since the greater part of the metropolitan see of Kiev, which had jurisdiction over all Byelorussia and the Ukraine, lay within the dominions of the Polish Lithuanian Commonwealth, it owed no obedience to Moscow, and neither the Orthodox nor the Greek Catholic Churches of the Grand Duchy of Lithuania adopted the so-called 'Nikonite' reforms. The Iosifskij text continued to be used by the Byelorussian Orthodox Church until the annexation of the Grand Duchy of Lithuania by Russia at the end of the 18th century, and by the Greek Catholic Church until its suppression in 1839. This accounts for the divergences, sometimes marked, between the texts of 17th and 18th century Byelorussian and Russian Irmologia.

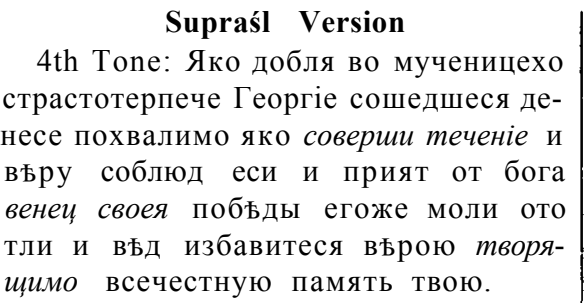

\section{Moscow Synodal Version}

4th Tone: Яко добля въ мученицьх страстотерпче Георгіе сошедшеся днесь восхвалимь тя яко теченіе совершивъ веру соблюдь еси и прият от бога побъды твоея венеиь егоже моли от тли и бъдь избавитися в-рою совершающим всечесную память твою. 
An interesting feature of the Supraśl podobny texts, and indeed of the whole Irmologion is the persistance of the former tendency to assimilate the half-vowels ' $\mathrm{b}$ ' and ' $\mathrm{b}$ ' to the letters ' $\mathrm{e}$ ' and 'o' respectively. Even where these half-vowels are not actually written into the text as full vowels, it is evident from the melody itself that these 'soft' and 'hard' signs ' $b$ ' and ' $\mathrm{b}$ ' were to be given the value of full vowels, and extensive vocalisations were often sung to them. This practice known as chomonija, was widespread throughout the East Slavonic world until the beginning of the 17th century, when it began to disappear. ${ }^{39}$ It is clearly discernible in the podobny texts of $\mathrm{BN}$ Aks. 2954, which would seem to date from the mid-16th century, and is found to a lesser degree in the texts of the Supraśl Irmologion of 1601. In Cz. 2055. I., which is of somewhat later date, probably the first quarter of the 17th century, instances of chomonija are rarer still.

So it is that one finds in the Supraśl podobny the forms 'ото языко' instead of 'оть языкъ'; 'мученихомо' instead of 'мученихомъ'; 'человъколюбече' for 'человъколюбче'; 'о душахо нашихо' for 'о душахъ нашихь' (though this latter form also is used, indicating a transitional period in which the practice was falling into disuse), and 'бывоше' instead of 'бывше'. The more distorted forms of 'денесе' for 'днесь', 'конецы', for 'концы', and 'вонутре' for 'внутре' found in BN Aks. 2954, are seldom if ever encountered in the Supraśl texts.

On the other hand the texts of the Supraśl Irmologion, including the podobny texts, display certain features which suggest a certain influence of the Byelorussian vernacular on the original Church Slavonic language. These features are relatively few in number, and do not appear in the podobny with any kind of consistency. They may be ascribed rather to unconscious slips by the copyist, than to the existence of a specifically Byelorussian version of the old Slavonic texts. Hence one occasionally finds the characteristic forms of 'Tобе' and 'Тебе' instead of 'Тебъ', 'ражаетеся' instead of 'раждаетеся', 'свято' for 'свето' and 'светая' for 'святая'. The hypothesis of copyists' slips is plausible when it is remembered first that the compiler was a native of Pinsk who inserted several notes in the Irmologion in the Middle Byelorussian language. ${ }^{40}$

The melodies of the Supraśl podobny present considerably more individuality and interest than the texts which, after all, remain reasonably close to the Church Slavonic originals.

Certain collections of podobny from East Slavonic sources, particularly from North Russia and from the Carpatho-Ukraine, divide the melody of each podoben into a given number of sequences or kolena. In the case of the Carpatho-Ukrainian Prostopenije, which is a collection of recent date, these sequences are identified by dividing the melody into a number of bars. Whether this has any significance beyond a matter of convenience is not clear. The North Russian Valaam Obichod on the other hand, is clear and specific in defining the number of sequences or kolena comprised in each podoben. The number may vary from six kolena as in the podoben of the 1 st tone 
'Небесных чинов', to twelve in the podoben of the 6th tone 'Совъть превъчныи'. Other podobny such as that of the 5th tone 'Радуйся живоносны кресте' are described as having no determined number of kolena ('опредъленнаго числа кольнъ не имъетъ'). ${ }^{41}$

No such detailed division of the podobny melodies into a given number of kolena is discernible in the Supraśl Irmologion, BN Aks 2954 or Cz. 2055. I. and with the possible exeption of the somewhat anomalous Supraśl podoben of the 6th tone 'Ангелския предо идуте', no use is made of bar lines. It is true that certain melodic patterns or papieŭki are to be found in the Supraśl podobny, and that these may recur within the same stichira, or in another stichira of the same tone. The essence of the Valaam kolena is that they are nonrecurring, so no useful analogy can be drawn with the Supraśl chants on this feature.

The notation of the Supraśl Irmologion is based essentially on a system of linear or staff notation which appears to have come to Byelorussia from the West during the latter half of the 16th century. This may be deduced from the fact that the inventory made in Suprassl at the order of the Archimandrite Sergius Kimbar in 1551, reveals the existence in the monastery library of four Irmologia, all written in the neumatic or znamenny notation. No mention is made of any books of chants recorded in any other kind of notation. ${ }^{42} \mathrm{BN}$ Aks. 2954, which is thought to date from the mid-16th century, is an instance of the prevalence of the znamenny notation at this time. Fifty years later Bohdan Anisimovič was making use of the linear system in compiling the Supraśl Irmologion at that same monastery, and even transcribing znamenny melodies. Since there are no earlier recorded Irmologia in which staff notation is to be found, its acceptance must have taken place at some time between 1551 and $1601 .{ }^{43}$ This probably came about as a result of the religious upheavals of the time, when large numbers of Orthodox laymen and even clergy, embraced the fashionable religious movements of the Reformation, and later of the counter-Reformation. Reconversions to Orthodoxy were by no means rare, and they doubtless brought in their train a measure of Calvinist and Catholic influences. A Calvinist Catechism was published in Niaśviž in 1562, containing a number of canticles or kantyčki recorded in linear staff notation, and this, according to Voznesenskij, may well have been the origin of the notation used in the Supraśl Irmologion. ** This suggestion is certainly plausible, when a comparison is made between the form of certain notes as used in the Niaśviž Catechism - particularly the breves, semibreves and minims - and the corresponding notes of the Supraśl collection. The similarity is clear, even though the clean-cut quadrate notation of the former work has been somewhat debased in Anisimovič's cursive hand.

The value of the notes used in the Supraśl podobny became more or less standardised throughout Byelorussia and the Ukraine in the mid-17th century, and was adopted in Russia at the close of the century, though in a somewhat modified form. 
The Supraśl Irmologion comprises the following notes:
尹 $=$ takt or breve
$\checkmark=d$
četverty or minim
$=\mathbf{=} \begin{aligned} & \text { polutakt or } \\ & \text { semibreve }\end{aligned}$
$1=d$
polučetverty or crotchet

$$
v=\nabla \quad \begin{gathered}
\text { pol-polučetverty } \\
\text { or quaver }
\end{gathered}
$$

The breve, as used in the Supraśl Irmologion appears quite frequently, which leads one to believe that in singing, it must in effect have had the value of a semibreve. The most commonly used notes are the polutakt (semibreve) and the četverty (minim). The polučetverty (crotchet) is used infrequently, and the pol-polucetverty (quaver) appears very rarely indeed. The breve is only found in the earlier manuscripts, such as Cz. 2055. I: by the mid-17th century its form, and probably also its relative value, had evolved, and it was being used only as a final breve to mark the ending of a canticle. In this latter form it appeared in the Žyrovicy Irmologion of 1661, and most of the later versions. On the other hand the pol-polučetverty (quaver) came into wider use at about this time, and it may be that the old symbol for the semibreve thereupon became the standard symbol for the breve.

The notation of the Supraśl Irmologion, as well as of Cz. 2055. I, was written in cursive script. Later Irmologia are recorded in a clearer quadrate form of notation which shows plainly the influence of printing.

The system of key signature used in the monastery of Suprasil followed standard Western norms. A staff of five lines is used throughout the Irmologion, the key signature being given by means of a $\mathrm{C}$ or alto clef placed on one of the four lower lines of the stave. The precise position of the $\mathrm{C}$ clef on the stave varies from stichira to stichira, depending on the demands of the melody of any given podoben, but out of a total of sixteen podobny chants in the eight tones, ten have the $\mathrm{C}$ clef on the third or middle stave, and five have the key signature on the fourth line from the bottom. One podoben 'Ангелеския предо идуте' begins with the $\mathrm{C}$ clef on the middle line, but the position of the clef changes to lower or first line at the words 'приими целование'.

Modulation of a note by flattening, is a common enough feature of the Supraśl system of notation, and is indicated by the usual be-mol (b) symbol used in Western Europe. Sharps are extremely rare but not unknown. Almost invariably the be-mol symbol when used, appears on the stave, immediately after the clef, and its use before a note in the middle of a chant is seldom, if ever, encountered. In most cases the be-mol is placed on the fourth line from the bottom, where 
the $\mathrm{C}$ clef is placed on the first line. Where the $\mathrm{C}$ clef is placed on the third or middle line, the be-mol falls between the second and third lines, and if the clef is placed on the fourth line from the bottom, the be-mol falls between the fourth and third lines.

In the podobny chants, all the melodies except the anomalous 'Ангелеския предо идуте' of the 6th tone, are so noted so that the seventh note ascending from the dominant, i. e. the subdominant is flattened. It follows that fifteen out of the sixteen podobny chants are in fact in the key of $F$, although the position of the clef varies between the bottom and the fourth line.

Although the podoben 'Ангелеския предо идуте' is here described as anomalous in that the melody changes key twice within a relatively short span, in the Supraśl Irmologion taken as a whole, as well as in other Byelorussian Irmologia of later date, this is not an unusual feature, though the effect these modulations produce is a little strange.

The character and melodic content of the Supraśl podobny chants does not differ substantially from those of the other chants described by Anisimovič as originating from the monastery of the Annunciation. Even a summary study shows that the melodies are generally broad and noble in feeling, and are infused with a dignity one would naturally associate with the interpretation and embellishment of liturgical texts. They are broadly speaking diatonic, having no chromatic intervals, apart from a few exceptions in those melodies which change key once or several times. The rhythm of the chant is that of free prose, in which the length of a musical phrase or sequence is determined by the length of the text. Although the podobny in Byelorussian Irmologia of later date contain the repetition of certain words or syllables, the Supraśl podobny are free of any such textual adulteration, and the melody is smooth, flowing and legato. Intervals of fourths and fifths are not uncommon, though these usually occur between sequences or phrases, rather than within a musical pattern or papieǔka. Occasionally one encounters intervals of sixths (cf. podoben of the 6th tone 'Ангелеския предо идуте') and even intervals of sevenths, though such instances are exceptional (cf. podoben of the 4th tone 'Даль еси знамение' at the words 'еси начало').

The range of the melodies of the podobny is variable, extending from chants comprised entirely within an interval of a fourth (cf. podoben of the 1st tone 'Небесныхъ чинов радованіе') to those within an interval of an octave (cf. podoben of the 4th tone 'Званыи совыше'), and even of a range from $\mathrm{A}$ below middle $\mathrm{C}$ to $\mathrm{C}^{\prime}$ (cf. podoben of the 6th tone 'Ангелеския предо идуте'). ${ }^{45}$

Although several of the podobny chants are written to be sung to the same tone, (е. g. the podobny of the 2nd tone 'Доме ефратово' and 'Егда ото древа'), they not infrequently diverge to such an extent as to present few or no features at all in common. There are however certain podobny of the same tone in which for example, the final sequences are related, and identical papieŭki recur. A study of these chants will reveal to what extent they are interrelated. 


\section{1st Tone}

There are two podobny of the first tone in the Supraśl Irmologion: 'Небесныхъ чинов' and 'Прехвалнии мученицы'. Both are in the same key ( $\mathrm{C}$ clef on the fourth line from the bottom, with a be-mol between the middle and fourth lines, $i$. e. the key of $F$ ), and share a relatively narrow melodic range. The melody of 'Небесныхъ чинов' extends from $\mathrm{G}$ to $\mathrm{D}^{\prime}$, and that of 'Прехвалнии мученицы' from $\mathrm{A}$ to $\mathrm{E}^{\prime}$. Between the two podobny there are but two recurring papieŭki, notably on the words 'крепкая помощнице' and 'древа животнаго' and on the final sequences 'богородице возложихомъ' and 'и велию милость'. Within the podoben 'Небесныхь чинов' there are two recurring papieǔki: the phrase sung to the words 'Небесныхь чинов радовате' is repeated at 'спаси нас во ти прибегающая'. Similarly the papieǔka sung to 'и на земли человека' also recurs on the words 'яко на тя уповаше'.

The podoben 'Прехвалнии мученицы' shows less symmetry of structure than the first. The papieŭka sung to the words 'потаила есте' recurs one half tone lower to the words 'слаждаетеся' and 'душамъ нашимъ'.

\section{2nd Tone}

The podobny of the 2nd tone 'Доме ефратово' and 'Егда ото древа' do not have a final papieŭka in common. 'Доме ефратово' shows considerable richness of melody and rhythm. The range is from D to B-flat, and there are no recurring papieǔki. 'Егда ото древа' on the other hand is a considerably lengthier chant, of more even melody and with less rhythmic variety. As in 'Доме ефратово' the melodic range extends from D to B-flat. One lengthy papieǔka recurs frequently to the words 'Аримафеи сонято весяческимо жизне, христе обвито и любовию под визящеся' and 'пречистое облобызати обаче сумнася боязнию'. Another recurring papieŭka is sung to the words 'из мирною плащаницею тя, сердце мои уста тьло' and 'вопіяще ти слава'.

\section{3rd Tone}

There is only one podoben of the 3rd Tone 'Велия креста твоего' in the Supraśl Irmologion. It is melodically rich and contains no repetition of any papieu ka. The melodic range extends from $\mathrm{D}$ to $\mathrm{C}^{\prime}$

\section{4th Tone}

There are three podobny of the 4th tone, and they are remarkable in that they are quite evidently closely interrelated. Similar papieŭki recur in 'Яко добла во мученицехо', 'Дал еси знаменіе' and 'Званыи совыше'. Thus the papieǔka to the words 'венец своея победы' in the first podoben recurs in the second 'Дал еси знаменіе' at the words 'темныя и власти'. Similarly the final sequence of the first podoben to the words 'всечестную память твою' is repeated in the second to 
the words 'и спасти душам нашим' and in the third to the text 'просветити душа наша'. Again the papieǔki to the words 'соблюд еси' and 'похвалимо' in the first podoben, are repeated to the words 'егоже моли' and 'облистая' respectively in the third. In the same way the papieǔka to the words 'верою творящимо' and 'бъд избавитися' in the first podoben recur to the words 'смотрение славимо' and 'древнее блаженство' respectively in the second.

There are however, no repetitions of papieǔki within the first two podobny of the 4th tone, though within the third podoben the pa-

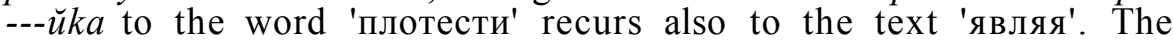
melodic range in the first podoben of the tone 'яко добла во мученицехо' is narrow, extending over an interval of one fourth, ranging from D to G. In 'Дал еси знаменіе' it extends a full octave from $\mathrm{C}$ to $\mathrm{C}^{\prime}$, and in 'Званыи совыше' from $\mathrm{E}$ to $\mathrm{E}^{\prime}$.

\section{5th Tone}

There is only one podoben of the 5th tone, 'Радуиися живоносныи кресте'. The range of the melody extends from D to B-Flat, and contains a proportion of recitative on one note. There are recurring papieüki to the texts 'Радуиися живоносныи кресте', 'церковное погражденіе' and 'воистинну украшеніе'. The papieǔka to the words 'непобедимое оружіе' recurs at 'имже тля разорися' and 'пристанище спасению'. The papieŭka to the word 'крепителю' recurs later to the text 'смертная держава'.

\section{6th Tone}

In the 6th tone there are four podobny to the text, 'Все упование', 'Третыи день воскресл еси', 'Неначаемая жития ради' and 'Ангелеския предо идуте'. They are distinguished melodically by the recurrence of relatively wide intervals of a fifth in the flow of the chant. In the podoben 'Все упование' the range of the melody extends from $\mathrm{D}$ to $\mathrm{C}$ '; in 'Третыи день воскресл; from $\mathrm{F}$ to $\mathrm{C}$ '; in 'Не начаемая жития' from $\mathrm{C}$ to $\mathrm{C}$ ', and in 'Ангелеския предо идуте' from A below $\mathrm{C}$ to $\mathrm{C}^{\prime}$.

The final papieŭki of the podobny 'Все упование' and 'Третыи день' are related, but the endings of 'Неначаемая жития' and 'Ангелеския предо идуте' are dissimilar. As the podobny of the 6th tone are melodically rich and varied, there are few recurring papieŭki between the chants of this tone.

The podoben 'Все упование' has internally recurring papieŭki at the words 'исцеление' and 'во всем послушиви', at 'собъ светая сокрыла есте' and 'евангелски не стажаста', and at 'неприяста тунеже' and 'бывоше Христови'. There are recurring papieǔki in the podoben 'Третыи день' at 'еси Христе из гроба' and 'славит род человьческіи'.

The podoben 'Неначаемая жития ради' has a papieŭka which is repeated at the words 'и увъдомая права ради'. The papieŭka to the text 'Не отоверзи мене блуденицу рождеися ото дъвы' is repeated 
to the text 'не презри слезо моихо радости ангеломо'; the second half of this papieǔka appears initially to the words 'ко тобъ вопиюще'. A shortish papieüka also recurs to the words 'но приими мя' and 'каюшуся'.

The podoben 'Ангелеския предо идуте' however, has a recurring papieŭka, to the texts 'радосте богородице', 'людие рецемо' and 'благословенно рождеиства'.

\section{7th Tone}

The 7th tone has only one podoben: 'Нектому возбраняеми'. This chant has a relatively narrow range, extending from $\mathrm{G}$ to $\mathrm{C}^{\prime}$. It has a recurring papieǔka to the words 'возбраняеми есмы' and 'упование имуще'. Together with the podoben of the 2nd tone 'Доме ефратово' it is the shortest of the podobny.

\section{8th Tone}

The chants of the podobny of the 8th tone have a wide melodic range. 'О преславеное чудо' extends from $\mathrm{D}$ to $\mathrm{C}$ ', and 'Что вы наречемо' ranges from $\mathrm{F}$ to $\mathrm{D}^{\prime}$. Since the endings of the two chants are entirely dissimilar, and as there are no recurring papieǔki, it is difficult to trace any discernible kinship between the two podobny. 'O преславеное чудо' has no internally recurring papieŭki. It contains a number of extended recitative passages, which mark it out as one of the melodically poorer podobny. 'Что вы наречемо', on the other hand, has one recurring papieŭka at the words 'херувим ли яко на вас, серафими ли яко выку' and 'молите о спасении душе'.

It is perhaps a little premature to speculate at this stage on the origins of the Supraśl chant as a whole, and of the podobny chants of the Supraśl Irmologion in particular. Voznesenskij has expressed the general view that what he called the jugo-zapadnyje chants, as well as those of Russia proper, were derived initially from the palaeo-Slavonic znamenny or stolpovoje chant. ${ }^{46}$ Even as the Muscovite cantors in the 16th and 17th centuries added to the old chant to embellish it and create new variations, so also did the Byelorussian and Ukrainian masters alter the chant by introducing ornamentation, abbreviations, and fresh melodic variations which were in keeping with local tastes. ${ }^{47}$ This theory is certainly plausible, but it does not appear to take into account the fact that there was in existence in Byelorussian Irmologia at the end of the 16th century, a considerable corpus of znamenny chants. These are akin to the znamenny chants of Moscow, though the differences which do exist are probably attributable to variations in national or regional tastes, as Voznesenskij suggested. Either there were two variations of the znamenny chant in Byelorussia - one more closely related to the Russian version, and one more remote, namely the 'south-western' chant, - or else there existed in Byelorussia, in addition to the local variant of the znamenny chants, several other bodies of chants derived from other sources. Until more information is made available, the question must remain an open one. 
There did however exist, even in the early 17th century in Byelorussia, a considerable number of 'local' chants - Mirski, Stucki, Vilenski, Smalenski, and Žyrovicki napievy. ${ }^{48}$ It is hardly suprising, therefore, to find the independently-minded monks of Supraśl pressing claims to have chants and liturgical customs of their own. It should be borne in mind, when examining these claims, that at the time when Bohdan Anisimovič and his colleague I. T. were compiling their collections of Supraśl chants, the monastery had existed as a properly constituted community for less than one hundred years. It is also known that the monks who restored the monastery in 1504, came from Kiev. Naturally one is led to surmise that the Supraśl chants may well have been adaptations or variants of existing Kievan chants. It is likely that the Supraśl singers, anxious to establish their own traditions in the field of Church music, as well as in liturgical usage, consciously varied and embellished the chants they had brought with them and so in a few decades, created an indigenous Supraślski napieŭ. Voznesenskij advanced the view that all the 'southwestern' Irmologia had derived from a common source, ${ }^{49}$ and the evidence seems to point in this direction, at least insofar as the podobny chants of the Supraśl Irmologion are concerned. Such chants would in any event, by their relatively restricted use, evolve far less, and absorb fewer local vernacular influences than hymns of the Liturgy such as Cherubiki and the chants of the Canon, which were in almost daily use.

Nevertheless, a comparison between the Supraśl podobny, and those of the L'vov Irmologion of 1700, for example, shows that, despite certain undeniable similarities in several of the chants, wide divergencies are very frequently encountered. Where similarities in the respective chants occur, they usually come at the beginning of a podoben. Then, after one or two papieüki which are either similar or related, the chants diverge considerably, and present few or no common features. On the other hand, several podobny chants of the Supraśl Irmologion have no parallels at all in the L'vov version.

Closer similarities are, however, discernible in the Supraśl podobny chants with the podobniki of other Irmologia of Byelorussian origin. Thus the chants of Cz. 2055. I. stand considerably closer to the Supraśl version than do those of the L'vov Irmologion of 1700. There are fewer divergencies from the common norm, though naturally such divergencies do occur between the two earlier versions.

It would, therefore, seem that the podobny chants of the Supraśl Irmologion fit into the general pattern of Byelorussian and Ukrainian liturgical music. As in the field of folk-song and paraliturgical chants, there was throughout the 16th, 17th and 18th centuries a continuing interaction between the two musical traditions, and Ukrainian Church chants were a common feature of later Byelorussian Irmologia, even as Byelorussian choirbooks and cantors were to be encountered in the Ukraine. It is interesting to note, for example, in the Žyrovicy Irmologion of 1661, two chants for the post-Communion doxology 'Да испольнятся уста наша', one entitled 'ББлорусское' and the other 
as 'Украинское'. Much more remains to be done, however, before the complete picture becomes apparent, and any significant conclusions can be drawn.

In transcribing the Supraśl podobny chants, an attempt has been made to present the melodies in a readily accessible form, whilst maintaining them at a reasonable pitch. The melodies have been transposed by altering the key-signature from a $\mathrm{C}$ to a $\mathrm{G}$, whilst leaving the notes in their original position on the stave. Where necessary the appropriate modulations have been made by introducing sharps and flats.

For practical reasons, as well as on the grounds given above, the takt has been given the value of a semibreve.

\section{NOTES}

1. D. Razumovskij, Cerkovnoje penije $v$ Rossii, Moscow, 1867-1869. S. Smolenskij, "Značenije 17 veka i jego "kantov" i "psalmov" v oblasti sovremennogo cerkovnogo penija tak nazyvajemogo prostogo napeva', Muzykal'naja starina, 5-6, StP, 1911. V. Metallov, Očerk istorii Pravoslavnogo cerkovnogo penija $v$ Rossii, Moscow, 1915. A. Preobraženskij, Kul'tovaja muzyka v Rossii, Leningrad, 1924. N. Findejzen, Očerk po istorii muzyki v Rossii s drevnejšich vremen do konca 18 veka, Moscow and Leningrad, 1928.

2. D. Razumovskij, op. cit, pp. 207-8. A. Preobraženskij, 'Latinskaja jeres' v russkom penii 17 v.', Orfej, Leningrad, 1922, pp. 193-201.

3. J. de Castro, Methodus cantus ecclesiastici Graeco-slavice, Rome, 1881; D. Malaškin, Notnyj obichod Kievo-Pečerskoj Uspenskoj Lavry, Kiev, 1885, Preface.

4. See in particular A. Preobraženskij, 'Ot uniatskogo kanta do pravoslavnoj cheruvimskoj', Muzykal'nyj sovremennik, 6, StP, 1915-1916.

5. For example, he affirms that the 'south-western' Irmologia do not contain any vocalisations to the seemingly senseless texts known as anenajki which are encountered in the ordinary texts of the Russian versions (p. 34). In fact such anenajki do appear in the earlier Byelorussian Irmologia, including the Supraśl collection, in which the text 'e-ne-na-ne-e-ne-ne-ne-na-na-nena-ne-na-ne' is inserted in the text Do levi $i$ blegoslovi hospo... da (Supr. Irm. f. 174). As to the so-called Greek chants (Grečeskije rospevy), Voznesenskij states categorically: 'v jugozapadnych notnolinejnich irmologach net ni odnogo' (p. 20), although several examples are to be found, both in the Supraśl Irmologion (Kiev State Public Library, AN. UkSSR Dept. of Manuscripts, Catalogue No. I, 5391) and in the later Zyrovicy Irmologion of 1661 (Ibid., No. I, 3367). His theory that stichiry such as the podoben 'Kto ty Spase rizu razdra' were composed to express the anguish of the Orthodox Church over the division caused by the Unija of Brest (1596) (p. 10), seems at variance with the fact that the podoben in question was in liturgical use in both the Uniate and in the Orthodox Churches simultaneously. Similarly the so-called Serbian chant, far from enjoying an ephemeral success as Voznesenskij suggests (p. 63), is encountered quite frequently in the Byelorussian Irmologia (Cf. Kiev, AN I, 3367).

6. L. Mucharynskaja, 'Pisali piscy ŭ Supraśli', Litaratura i mastactva, 74 (2240), Minsk, 1968, p. 4.

7. A. Preobraženskij, Očerk istorii cerkovnogo penija v Rossii, StP, 1910, p. 21.

8. M. Kulikovič, 'Pytańnie biełaruskaj Bahasłužby', Baćkaǔščyna, 12-13 (496497), Munich, 1960, p. 3. But see more recently H. Pichura, 'Carkoŭnaja muzyka na Biełarusi', Božym šlacham, 83-85, London, 1964.

9. More unfortunately, many priceless Uniate printed books and manuscripts were burnt on the orders of the Orthodox Bishop Joseph Siemaško at the time of the liquidation of the Unija (Cf. A. Maldzis, 'Pa śladach žyrovickich aracyj', Litaratura $i$ mastactva, 55 (2516), Minsk, 1970, p. 13. 
10. See in particular F. Dobrjanskij, Opisanije rukopisej vilenskoj biblioteki, Vilna, 1882, and A. Lebedev, Rukopisi Cerkovno-Archeologičeskogo Muzeja, I, Saratov, 1916.

11. Kiev, AN, I, 3367, ff. 1-4.

12. F. Dobrjanskij, op. cit., No. 123 (204).

13. Thus the Codex Premisliensis, hereinafter referred to as BN Aks. 2954, although written in Byelorussia (a signed manuscript note by A. Petruševič records it as an 'Irmolog pod krjukovymi notami s $16 \mathrm{veka}$... belorusskij spisok') was kept for many years in the library of the Greek Catholic Capitula in Przemyśl, western Galicia.

14. This is particularly true of the chants of the Divine Liturgy and the AllNight Vigil, sometimes described as Kievskij. Many paraliturgical kantyčki and kalady are common to both Byelorussia and the Ukraine.

15. On the liturgical reforms under Nikon, and their effect on Russian church music see S. Smolenskij, Azbuka znamennogo penija... starca Aleksandra Mezenca, Kazan, 1888; Johann von Gardner, 'Einiges über die Orthographie der altrussischen Neumen vor der Reform 1668', Welt der Slaven, V, 2, Wiesbaden, 1960, pp. 198-213, and 'Einiges über den Singmeister Alexander Mezenec', Welt der Slaven, XII, 2, Wiesbaden, 1966, pp. 173-179.

16. The whole question of Byelorussian Old Slavonic texts, and their philological value has yet to become the subject of adequate study.

17. I. Voznesenskij, Cerkovnoje penije Pravoslavnoj jugozapadnoj Rusi, I, Moscow, 1898 , p. 8.

18. H. Pichura, 'Carkoŭnaja muzyka na Biełarusi', Božym šlacham, 83, pp. 11-2; 84, pp. 6-7, London, 1964.

19. Je. F. Karskij, Belorussy, I, 1, Warsaw, 1903, p. 141.

20. A. Freobraženskij, Očerk istorii cerkovnogo penija v Rossii, StP, 1910, p. 21.

21. H. Pichura, 'Bohdan Anisimovič', Božym Šlacham, 97, London, 1966, pp. 8-12.

22. Initially the manuscript was in the library of the Kievo-Pečerskaja Lavra. It is now in the Department of Manuscripts of the State Public Library, the Academy of Sciences of the Ukrainian S.S.R., Kiev. The Irmologion is entered in the catalogue entitled Litovskije Rukopisi under the reference No. I, 5391.

23. For a general account of the history and traditions of this monastery see Archimandrite Nikolaj (Dolmatov), Supraslskij Blagoveščenskij Monastyr', StP, 1892.

24. Cf. f. 56.

25. Cf. f. 57.

26. The demestvenny chants of the Supraśl Irmologion do not appear to constitute a separate and distinctive body of chants as in Russia. Ff. 49 to 71 are each headed Penije demestvennoje or Spievanie demestveny alternately. Nevertheless they include several chants which are specifically described by the copyist as Napietu Supraskogo. In this context the word demestvenny may mean 'local'. (Cf. H. Pichura, 'Carkoŭnaja muzyka na Biełarusi', Božym šlacham, 83, London, 1964, p. 13, n. 22.)

27. H. Pichura, 'Bohdan Anisimovič', 97 Božym šlacham, London, 1966, p. 9.

28. Cf. BN Aks. 2954, ff. 135-143; Supr. Irm., ff. 49-71; Cz. 2055, ff. 20-38.

29. Cf. f. 49.

30. Archimandrite Nikolaj, op. cit., p. 48.

31. Cf. note 13.

32. Department of Manuscripts, catalogue reference Rkp. 2055. I.

33. K. Nikol'skij, Posobije $\kappa$ izučeniju Ustava Bogosluženija Pravoslavnoj Cerkvi, StP, 1907, pp. $197 \mathrm{ff}$.

34. The term papieüka is here used to describe a musical sequence of some length, rather than in the sense of the Russian word popevka, a short snatch or pattern of the neumatic znamenny chant.

35. K. Nikol'skij, op. cit., p. 197 , note 2.

36. Osmohlasnik, ellinski že Oktoich, Institut Stavropigijskij, L'vov, 1895, pp. $252,686$.

37. The change in the order of the podobny of the 6th and 8th tones in BN Aks. 2954 and Cz. 2055. I. has no particular significance.

38. Cf. note 15

39. D. Razumovskij, op. cit., p. 264. 
40. For an analogous study in relation to Ukrainian Irmologia see Johann von Gardner, 'Zur Frage der Verwendung des Sema Fita in den altrussischen liturgischen Gesangshandschriften mit linierter Notation', Abhandlungen der Geistes- und Sozialwissenschaftlichen Klasse, 9, Mainz, 1970, pp. 283-93.

41. Cf. Obichod odnogolosnyj Cerkovno-Bogoslužebnogo penija po napevu Valaamskogo Monastyrja, Valaam, 1909, pp. 6, 33, 34, 44, 55, 76, 96.

42. Archimandrite Nikolaj, op. cit., p. 60.

43. The religious Union of Brest, which in 1596 united the Catholic Church and the majority of the Orthodox bishoprics in Byelorussia, must have assisted the diffusion of Western musical traditions. Although there is some evidence that polyphony and, therefore, linear notation were being used in L'vov in the $1580 \mathrm{~s}$, no collections of chants in the Western notation dating from this period have yet been brought to light.

44. I. Voznesenskij, op. cit., p. 22.

45. For practical reasons the melodic ranges of the podobny chants in the following section have been given in the tonic sol-fa.

46. I. Voznesenskij, op. cit., p. 14.

47. Ibid., pp. 15,35 .

48. H. Pichura, 'Carkoŭnaja muzyka na Biełarusi', Božym šlacham, 83, London, 1964, pp. 12-3.

49. Cf. notes 46 and 47.

\section{THE PODOBNY TEXTS OF THE SUPRAŚL IRMOLOGION (compared with other podobny texts of Byelorussian origin)}

\begin{abstract}
BN Aks. 2954
1st Tone

Небеснымъ чиномъ радование и на земли человъкомо крьпкая помощнице чистая дъво спаси ны к тебъ прибъгающая яко на тя оупование со богом богородице возложихомо.
\end{abstract}

Прехвалении моученици вас ни земля потаила есте но небо приято вы отоверзошася вам раиския двери и воноутре бывоше древа животнаго наслажаетеся христа молите даровати доушамо нашимо и велию милость.

\section{2nd Tone}

Доме ефраитово и граде святыи пророкомо слава оукраси домо во немеже божественыи раждаетеся.

Егда ото древа тя мертва аримофеи сонято весяческимо жизне и 3 мирною плащаницею тя христе обвито и любовию подвизашеся сердецеме и оусты тъло твое пречистое облобызати обаче соумняся боязнию радоуяся вопияше ти слава человъколюбече твоемоу смотрению.

\section{Supraśl Irm.}

Небесныхъ чинов радованіе и на земли человека крепкая помощнице чистая дъво спаси нас ко ти прибегающая яко на тя упованіе со богомъ богородице возложихомъ.

Прехвалнии мученицы вас ни земля потаила есте но небо пріято вы и отоверзошася вам раиския двери и внутрь бывоше древа животнаго наслаждаетеся христа молите даровати душамъ нашимъ мир и велию милость.

Доме ефратово и граде святыи пророкомо слава украси домо во немже божестьвеныи раждаетеся.

Егда ото древа тя мертва аримафеи сонято весяческимо жизне и 3 мирною плащаницею тя христе обвито и любовию подвизашеся сердецемо и уста тьло твое пречистое облобызати облаче сумнася боязнию радуяся вопіяще ти слава человъколюбече твоему смотрению.
Cz. 2055. I.

Небесным чином радование и на земли человъкомо крБпкая помощнице чистая дъво спаси ны к тобъ прибъгающая яко на тя упование 3 богом богородице възложихомо.

Прехвалени мученици вас ни земля потаила есте но небо приято вы и отоверзошася вам раиския двери и въноутре бывоше древа животнаго наслаждаетеся христа мольте даровати доушам нашим мирь и велию милост.

\footnotetext{
Доме ефраифо и граде святый пророкомо слава и оукраси домо въ немеже божественный ражается.

Егда ото древа тя мертвая аримафей сонято весяческоимо жизни и 3 мирною плащеницею тя христе обвито и любовию подвизашеся сердедецеме и оусты тъло твое пречистое облобызати обаче сумняся боязнию радоуяся въпияшети слава человьколюбече твоему смотрению.
} 


\section{3rd Tone}

Велия креста твоего господи сила водроузи бо ся на мъсте и дътелествоуете во мире и показа ото рыбареи апостолы и ото языко моученикы и молятеся о доушахо нашихо.

\section{4th Tone}

Яко добля во моученицехо страстотерпче георгие сошедшеся денесе восхвалимо яко соверши течение и въроу соблюдъ еси и приято ото бога вънеце своея побиды егоже моли тля и бъдо избавитися вьрою творяшимо всечестноую памяте твою.

Даль еси знамение боящимся тебе господи крест твои всечестныи имже обличило еси начала темныя власти и возвел ны еси на древеное блаженство тьмже ти человеколюбное смотрение славимъ исоусе весесилне и спасе доушам нашимъ.

Званны свыше а не ото человъко егда земная тма омрачи очи плотести и невърствиеме обличая сътование тогдаже небесныи свъто облистая смышле ниеме свьто зрака благовърие являя глаголомо разоума тъмъ разоумъ и изведшаго изо тмы свъто христа бога нашего егоже моли спасти просветити доуша наша.

\section{5th Tone}

Радоуися живоносныи кресте благовьрия непобедимое ороужие двери раиская върнымъ крепителю церковное ограждение имже клятвы разорися и проклатие восприято и попрася сомертная держава и вознесохомся от земля к небеснымо ороужие непобедимое въсомь соупротивниче слава моученикомо преподобнымо яко воистинноу оукрашение пристанище спасению подаи мирови велию милость.
Велия креста твоего господи сила во друзи бо ся на мъсте и девствуете во мире и показа ото рибарев апостолы и ото языко мученики и молатеся о душахо нашихо.

Яко добля во мученицехо страстотерпече георгіе сошедшеся денесе похвалимо яко соверши теченіе и въру соблюл еси и прият от бога венец своея побьды егоже моли ото тля и бъд избавитися вьрою творяшимо все честную память твою.

Дал еси знаменіе боящимся тебе господи кресто твои честныи имже обличило еси начало темныя и власти из вел ны есина древнее блаженство темже ти человеколюбное смотрение славимо исусе всесилне и спасти душам нашим.

Званыи совыше а не ото человъко егда земная тма омрачи очи плотести и невърствиемъ обличая сьтование тогдаже небесныи и свъто облистая смышлениеме свъту мрака благовърие являя глаголомо разумя тьм разумъ изведошаго из тмы свято христа бога нашего егоже моли спасти и просветити душа наша.

Радуиися живоносныи кресте благовьрия непобъдимое оружие двери раи[с]кия вьрнымо крепи телю церковное пограждение имже тля разорися и проклатие восприято и попрася смертная держава и вознесохомся от земля ко небесным оружие непобедимое въсом сопротивниче слава мученикомо преподобным яко воистинну украшеніе пристанище спасени[ю] подая мирови тобою велию милость.
Велия креста твоего господи сила въдрузи бо ся на мъсте и дътелествуете во мире и показа ото рыбарев апостолы и ото языко моученики да молятеся о доушахо нашихо.

Яко добля во моученицехо страстотерпче георгие сошедшеся денесе възхвалимо яко соверши течение и въру соблюл еси и приято от бога вьнеце своея побъди егоже моли ото тля и бъд избавитися върою творящим всечестноую памят твою.

Дал еси знамение боящися тебе господи кресто твои пресвятыи имже обновило есте начала темныя и власти из вел ны еси на древнее блаженство тьмже ти человъколюбече смотрение славимо исоусе весесилене и спаси душа наша.

Званныи совыше а не ото человъко егда земная тма помрачи очи плотести и невърствиемо обличая сътование тогдаже небесныи свъто облистая смышлениемъ свъто зрака благовърия являя глаголомь разоума твм разоумъ имъ изведшаго из тмы свъто христа бога нашего егоже моли спасти и просвътити душа наша.

Радоуися живоносныи кресте благовърия непобъдимое ороужие двери райския вБрным оукрепителю церковное ограждение имъже тля разорися и проклатие въсприято и попрася смертная держава и възнесохомся от земля к небеси ороужие не побъдимое бъсом сопротивниче слава моучеником преподобным воистинноу оудобрение пристанище спасению подаяй мирови тобою велию милост. 


\section{6th Tone}

Весе оупование на небесехо положиша сокровище некрадомо себъ святая сокрыла есте тоуне прияста тунеже и дадите болящимо исцеление злата и сребра еванггелскыи не стежаста человъкомже и скотомъ благодъяние подаета да во всемъ послоушливъ бывоша христови содерзновениеме молитеся о доушахо нашихо.

Третии день воскресль еси христе из гроба якоже есте писано совоскресивъ праотеца нашего тьм славите тя родо человъческыи и поете твое воскресение.

Неначаемая жития ради и оувьдомая нрава ради мироносяще приде ко тобъ вопиюще не отоверзи мене блоуденицоу рожеися ото дъвы не презери слезо моихо радости аггеломе но приими мя кающуся еяже не оториноу согрешешоу ти господи велия ради твоея милости.

Аггелскыя предо идуте силы яже во вифлеоме оуготовайте ясли слово бо ражаетеся премоудросте приходите приими целование церкви на радость богородици людие рецъмо благословенъ рожеися бого наше слава тебъ.

\section{7th Tone}

Нектомоу возбраняеми есмы древа животенаго оупование имоуще крестъ твои господи слава тобъ.

\section{8th Tone}

О преславное чюдо животворяи садо кресте пресвятыи на высотоу воздвижемъ является денесе и славословять воси конеци земля прогоними бывають веси дъмони о божие дарование земныимо даровася имеже христе спаси доуша наша яко милосердъ.
Bce упование на небесех положисте сокровище некрадомо собъ светая сокрыла есте туне прияста тунеже и дадите болящимо исцеление злата и сребра евангелски не стажаста человъкомже и скотом благодъянія подаете да во всем послушли бивоше христови содерзновениеме молятся о душах наших.

Третыи день воскресл еси христе из гроба якоже есть писано совоскреси праотца нашего тьм же тя славит род человъческыи и поет твое воскресением.

Весе оупование на небесе хо положиша сокровище не крадомо себъ святая сокрыла есте туне прияете туне же и дадъте болящи мо исцвление злата и сребра евангелески не стяжаста человъкомже и скотоме благодъяния подаете да во всем послушливи бышове христови содерзновением молитеся о душахо нашихо.

Третый день воскресл еси христе из гроба якоже есть писанно совоскресив праотеца нашего тьме тя славите родо человьческий и поете твое воскресение.

\section{Неначаемая жития ради}

Неначаемая жития ради и увьдомая нрава ради и оуведомая нрава ради мироносящи прииде ко то- мироносяще прииде к тебъ бъ вопиюще не отоверзи вопиющи не отоверзи мене мене блуденицу рождеися блудницу рождеися ото ото дъвы не презри слезо- дъвы не презери слез мо мо ихо радости ангеломо ихо радосте ангеломо но но приими мя каюшуся ея- приими мя кающуся еяже же согрешему (ти) господи оторину согрешешоу госповелия ради твоея милости. ди велия ради твоея милости.

Ангелеския предо идуте силы яже во вифлиоме уготоваите ясли слово бо ражаетеся премудросте приходите приими целование церкви на радосте богородици людие рецемо благословенно рождеиства бого наше слава тобъ.

Нектому возбраняеми есмы древа животенаго упование имуще кресто твои господи слава тобъ.

О преславеное чудо животворяи садо кресто пресвятыи на высоту воздвижен является днесь и славословят веси концы земля прогоними бывають весь дъмони о божие дарование земным даравася имже христе спаси душа наша яко милосердъ.
Аньгелескыя предо идуте силы иже во вифлеоме уготовайте ясли слово бо раждаетеся премудросте приходите приими целование церкви на радость богородице людіе рецьте благословено рождейся боже нашь слава тобъ.

Нектому возбраняеми есми древа животенаго упование имуще кресто твои господи слава тобъ.

О преславенное чоудо животворяй садо кресте пресвятый на высоту въздвижем является денесе славословят веси конци земля устрашаютеся бъсоская ополчения о како во дарование земнымо даровася имеже христе спаси душа нашая яко милосердъ. 
Что вы наречемо святии Что вы наречемо святии Что вас наречемо святий хероувими яко на васъ по- херувъм ли яко на васъ по- хировимли яко на вас почило есте христосо серафи- чило есте христосо сера- чило есте христосо серами и яко непрестани но фемъ ли яко выку просла- фим ли яко непрестани но прослависте его аггелы те- висте его ангелы тъла бо прослависте его ангелы ли ла бо отовратистеся силы отовратистеся силы ли дъ- тъла бо отовратистеся сыли дъете бо чюдеся многа -ствуете бо чудеся много лы ли дъете бо чюдеся ваша имена и болша даро- ваша имена и болша даро- многа ваша имена и болвания молите спастися вания молите о спасении -ая дарования мольте спадоушамо нашим. душе наших.

стися душамо нашим.

\section{THE PODOBNY CHANTS OF THE SUPRAŚL IRMOLOGION}

\section{「^ac 1}

A)

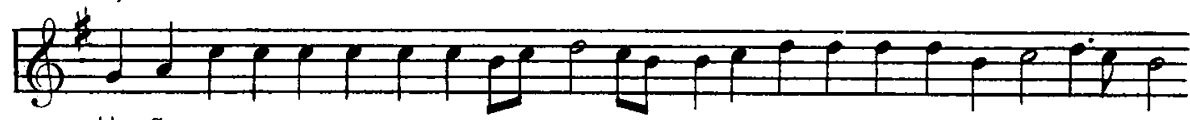

Не.бес-ныхьчинов ра- $\mathbf{-} \cdot \mathbf{\text { ва }}-\mathrm{Hi}-\mathrm{e}$

и на зем-ли че-ло-ве - ка

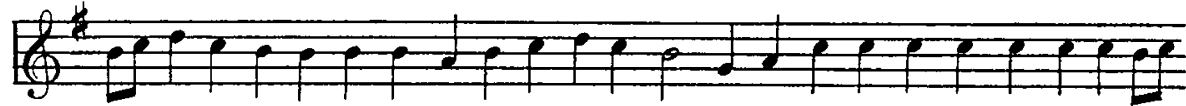

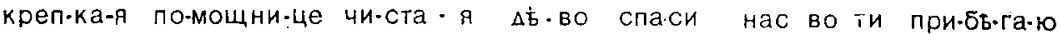

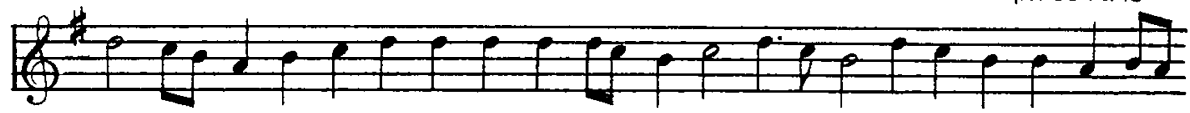

ша-я я-ко на тя у - по-ва-ні - е со богомъ Бо.го.ро.

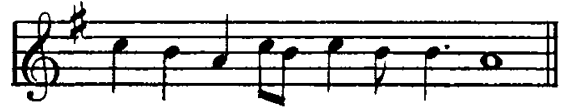

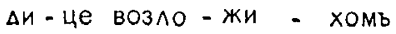

B)
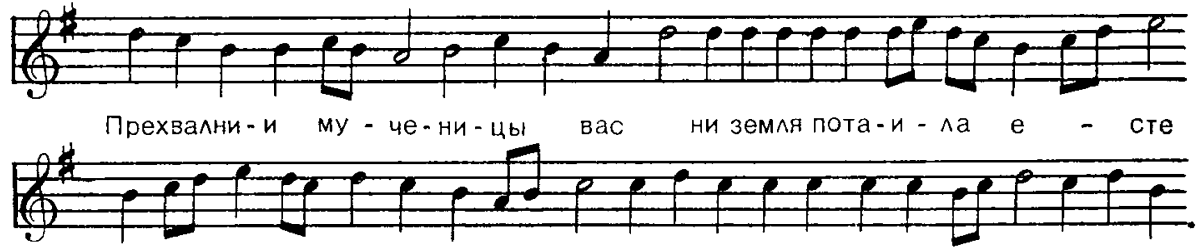

но не - бо прі - я - То-вы

и о-то вер-зо-ша-ся вам ра-и-ски-я
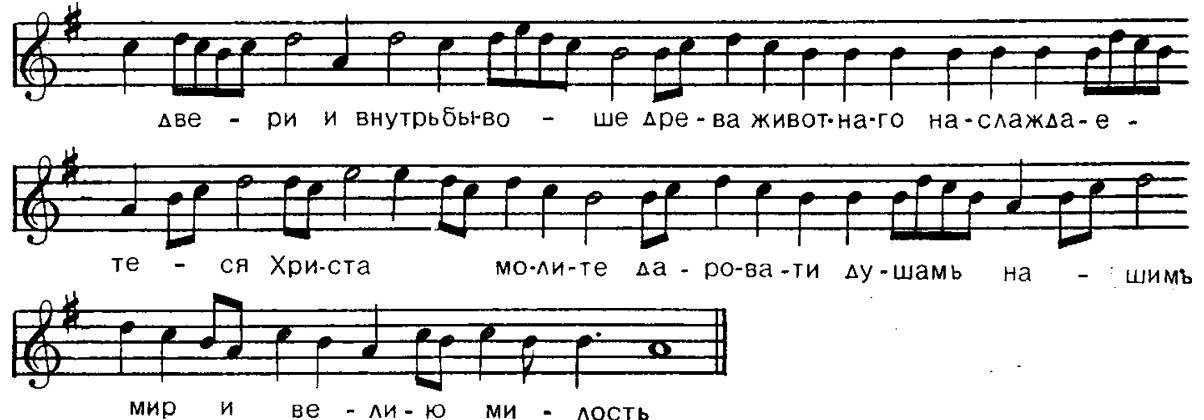
rıac 2

A)
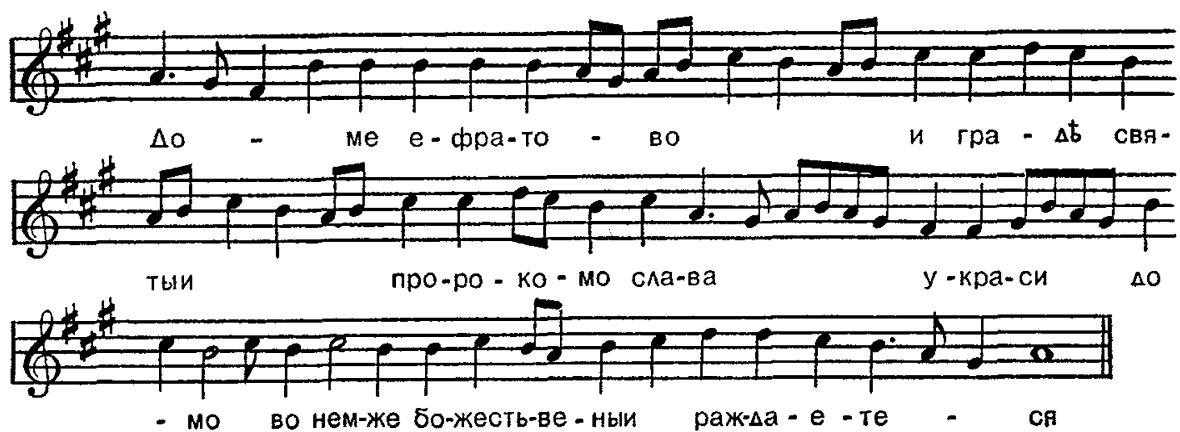

B)

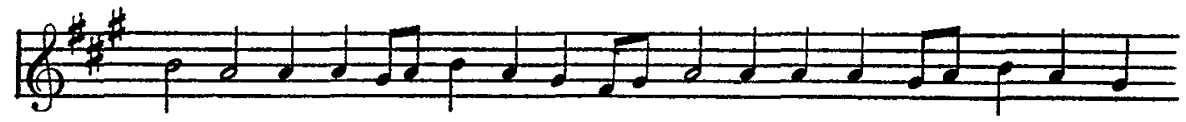

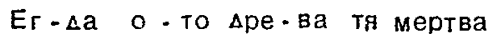
А - ри-ма - фе - и со - ня .
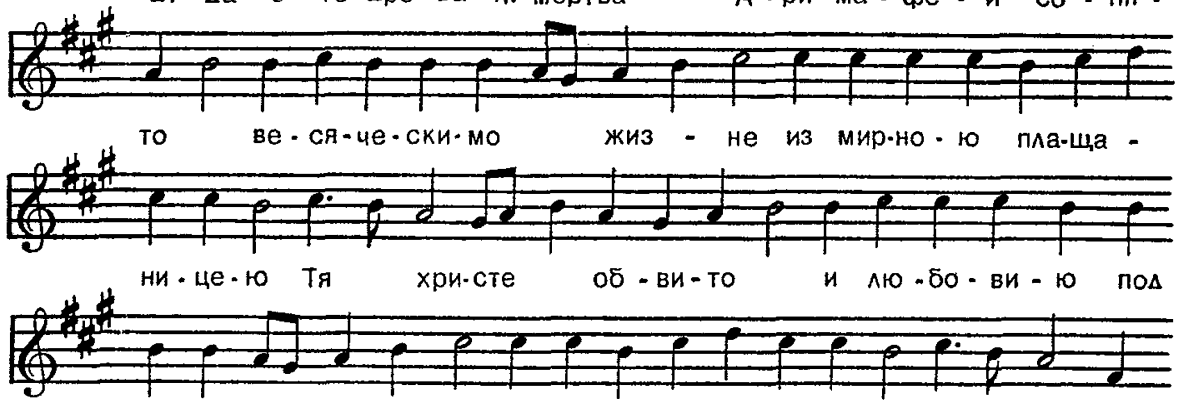

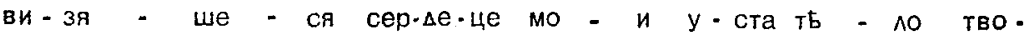
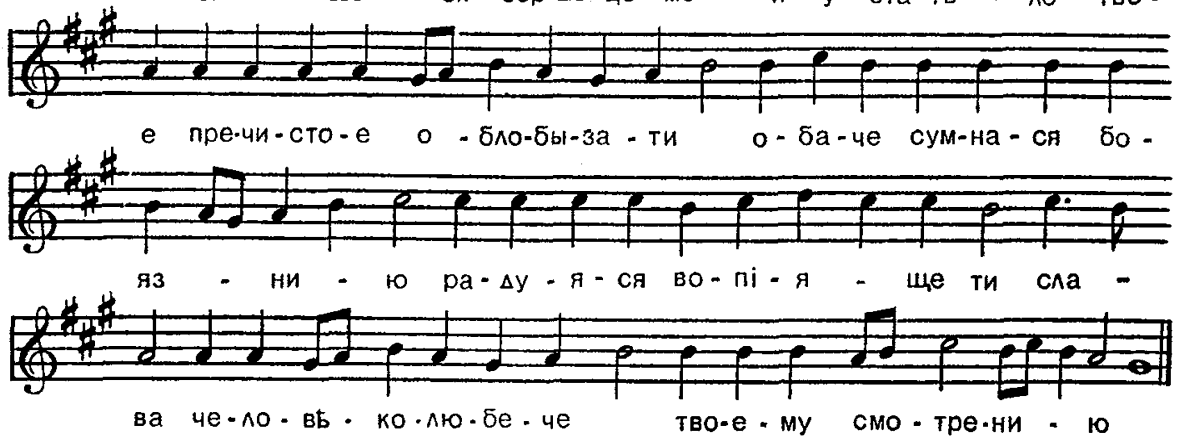

$\operatorname{raac} 3$

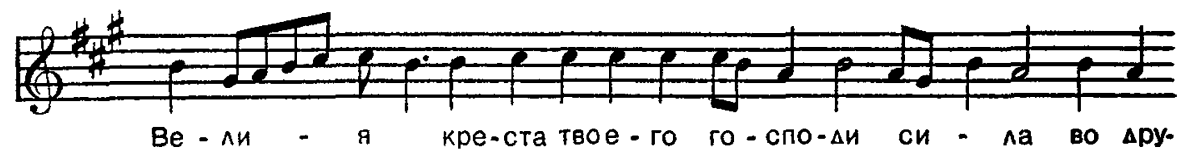




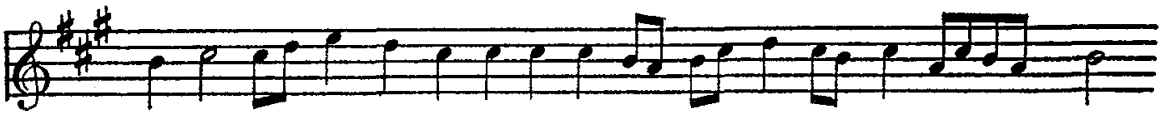

зи бо ся на мь-сте и Аев-ству - е - те во ми - ре
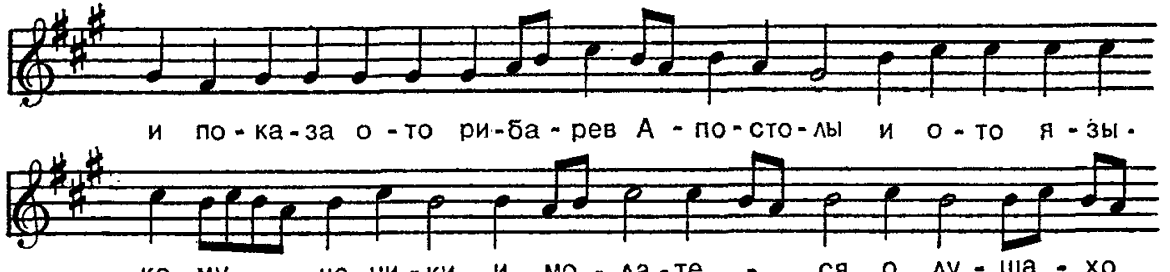

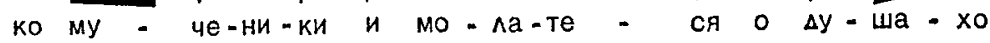

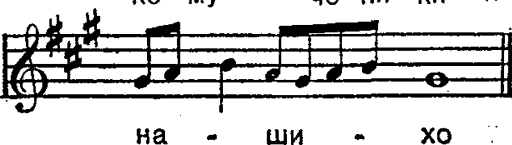

Face 4

A)

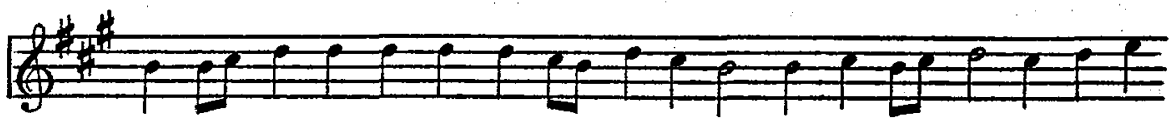

Я. ко $\Delta о . \delta \wedge а$ во му-че - ни-це.хо страсто.тер - пе.че ге.ор-
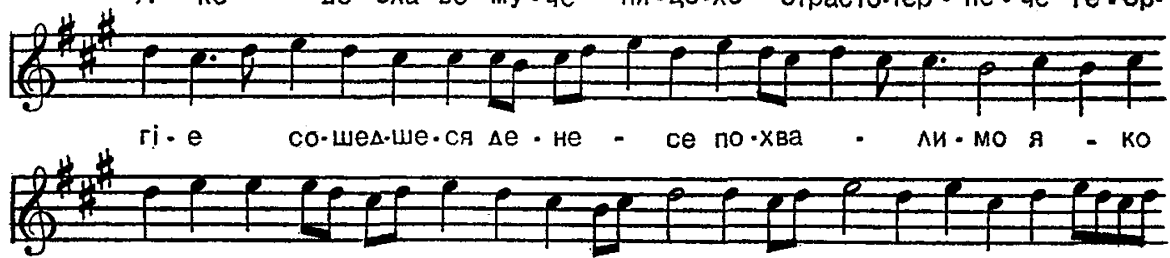
со -вер-ши те - че - ні - е
n Bt - py $\mathrm{CO} .5 \wedge \mathrm{H} \mathrm{e}$.
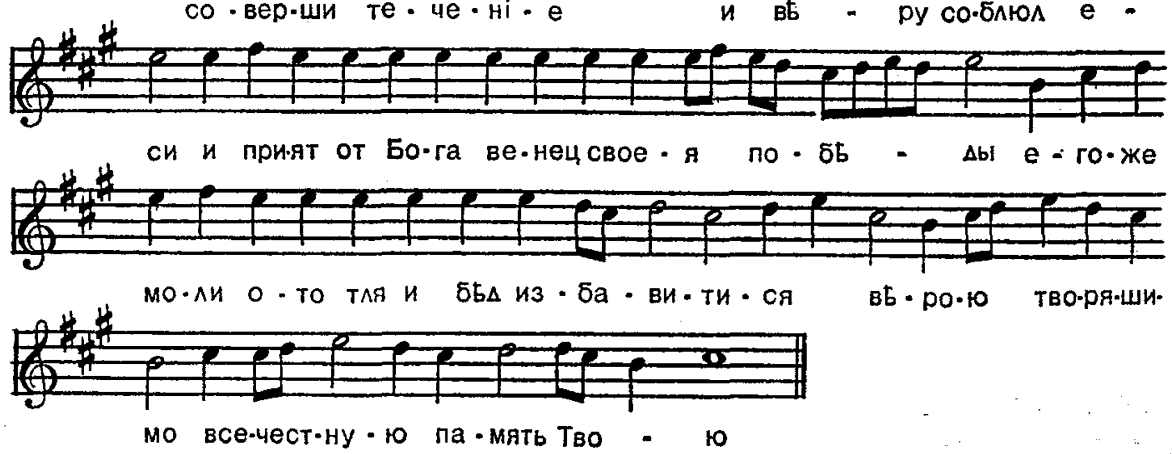

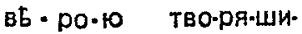

B)

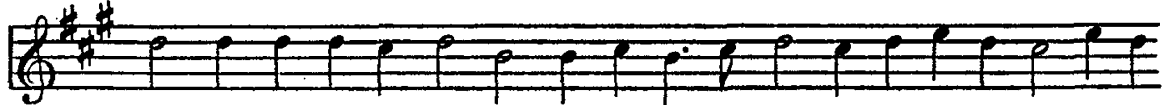

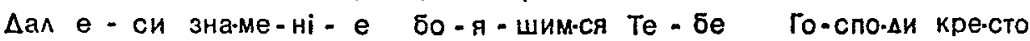

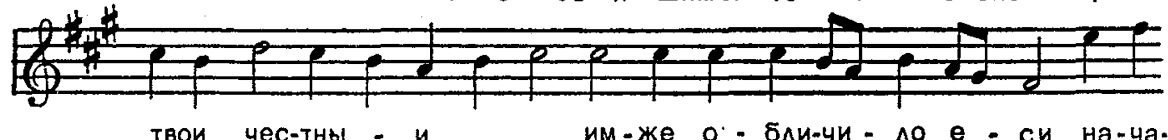



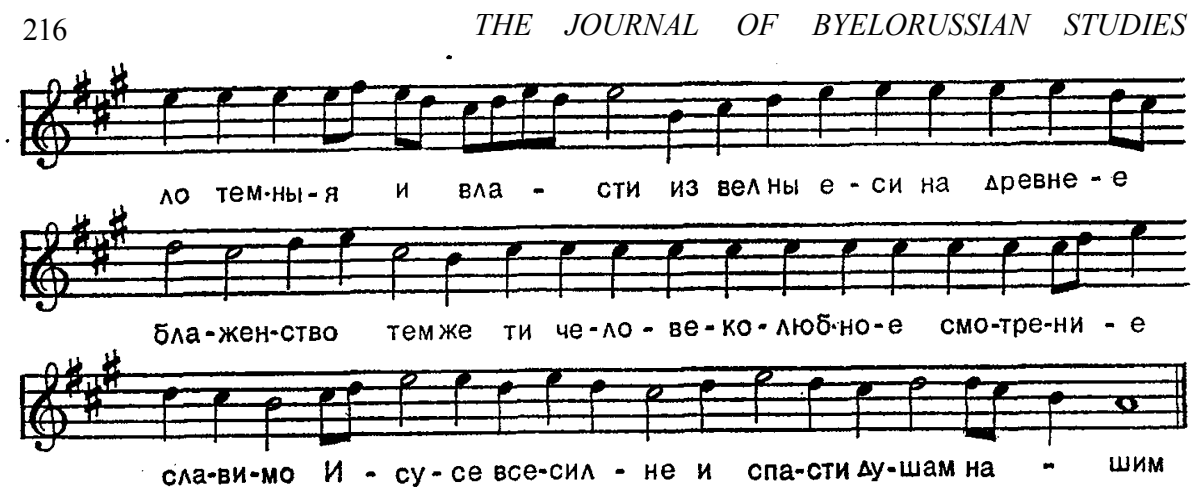

r)
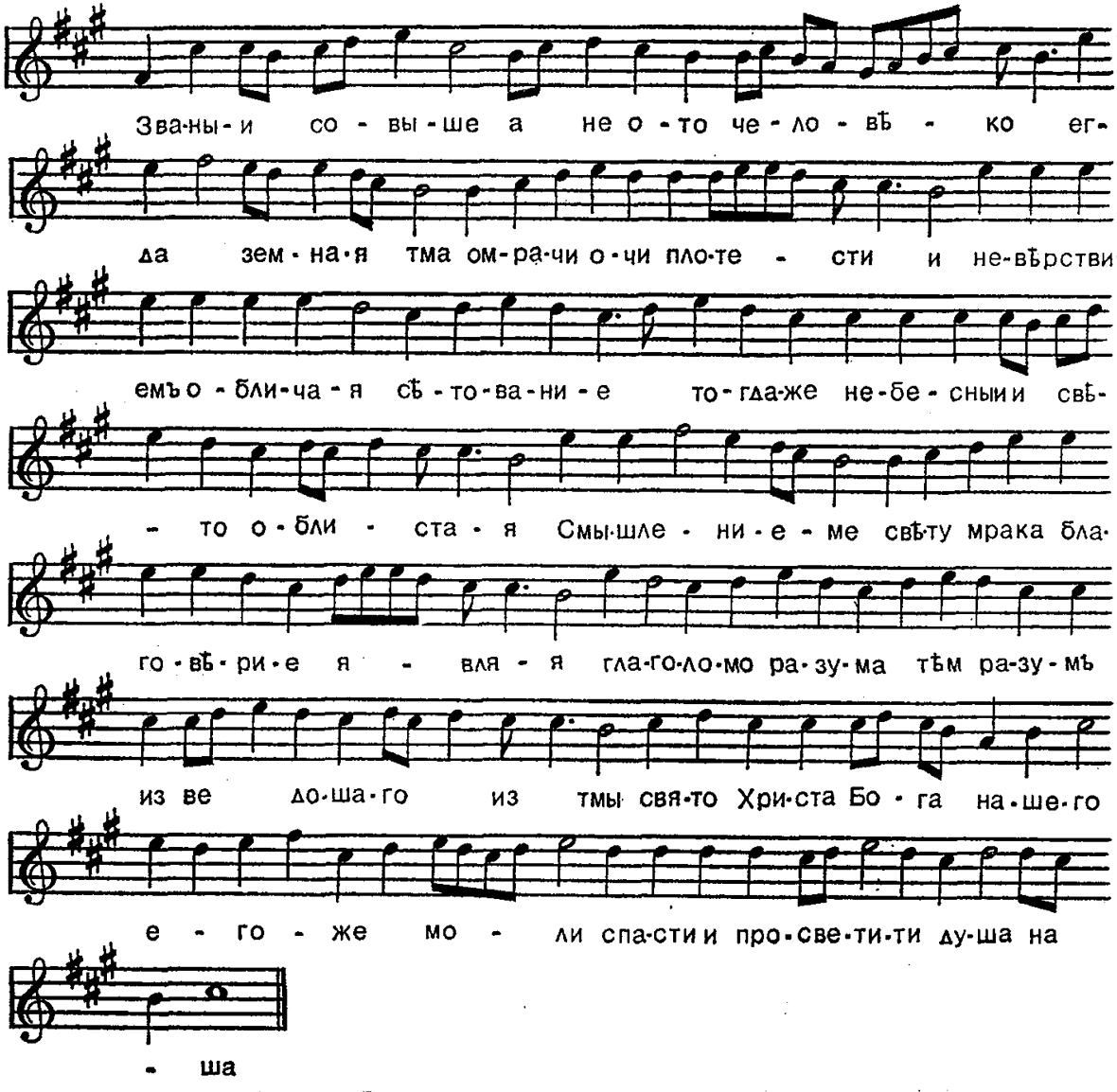

\section{TAac 5}

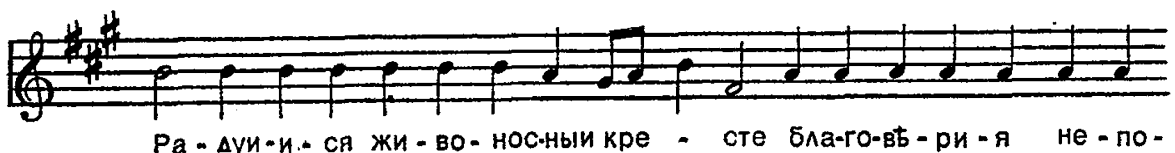




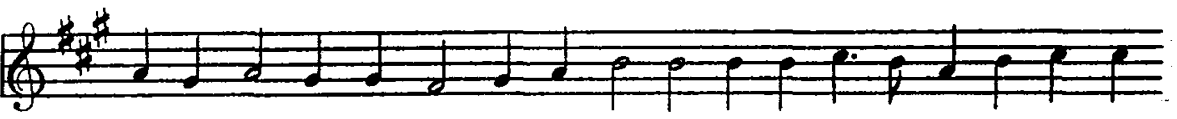

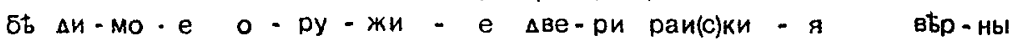

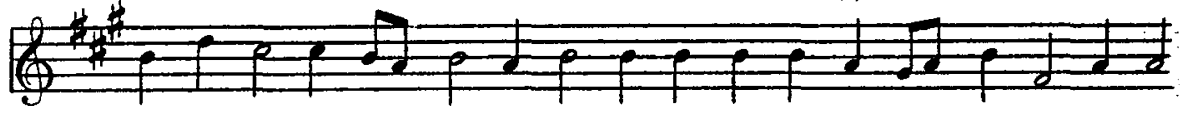

мо кре-пи-те - мю цер-ков-но-е по-гражАе-ни - е им-же

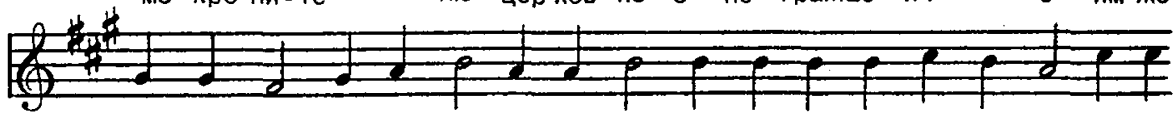

тАя ра-30-ри - ся и про-кла-ти-е вос-при-я - то и по-
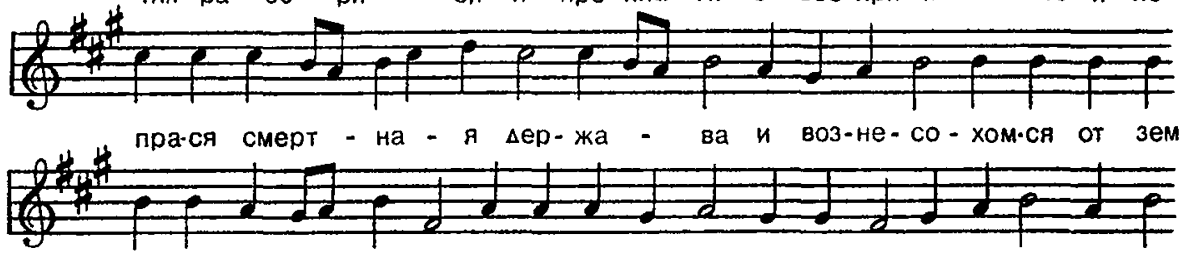

пя ко не-бе - снымо- ру-жи-e не по-бе-
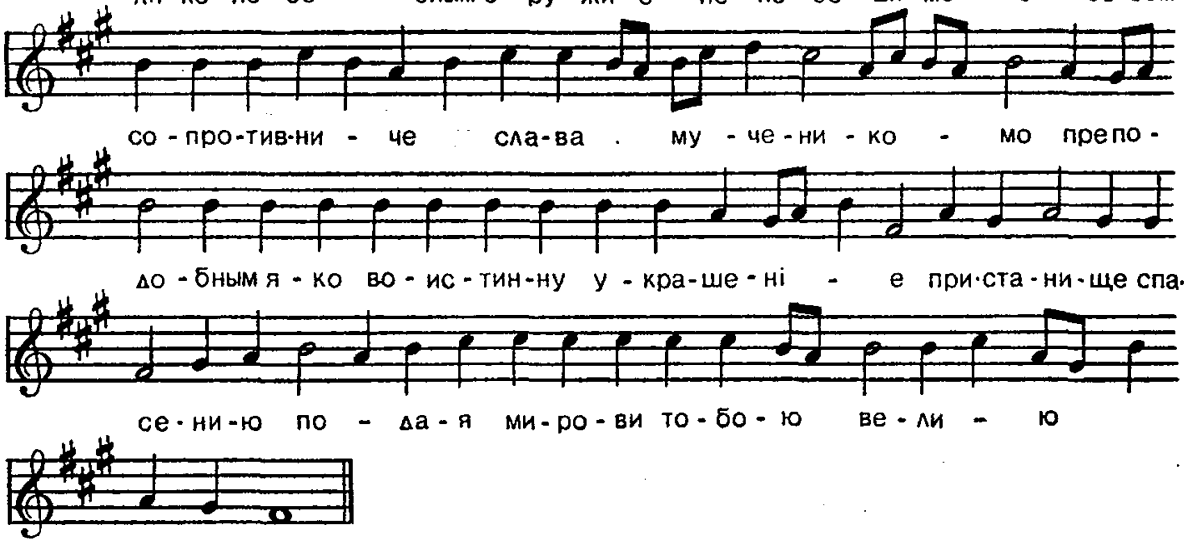

ми - NOCTь

\section{TAac 6}

A)

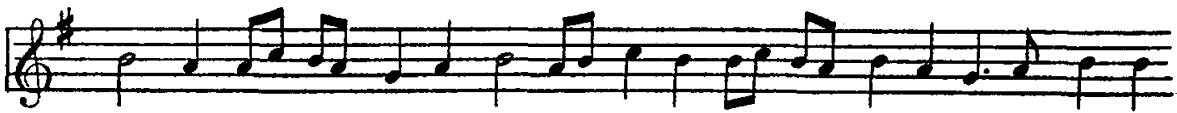
Bсе у-по-ва- ни . е на не-бе-сех по- - о-жи-сте со-кро-
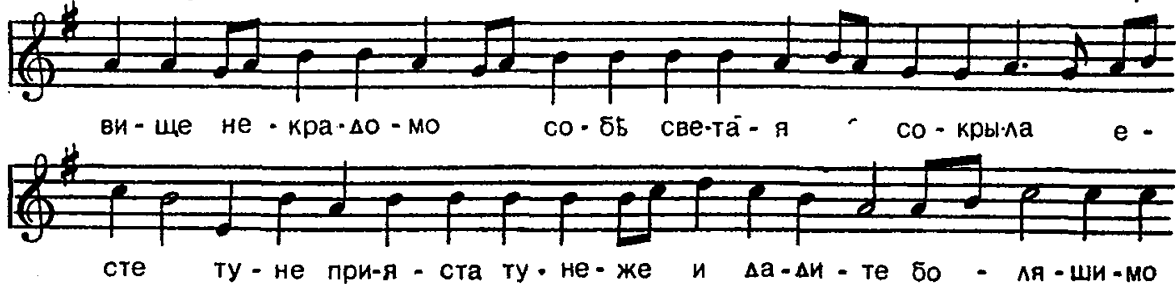


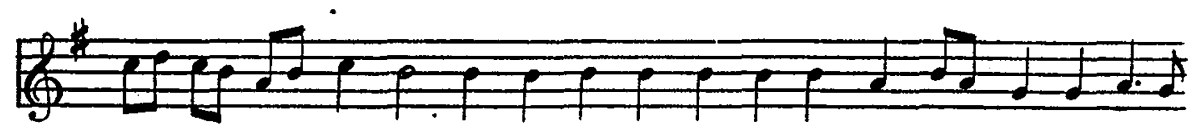
и - сие-ле- ни-е зла-та и сре-бра е-ван-гел - ски не ста(f)

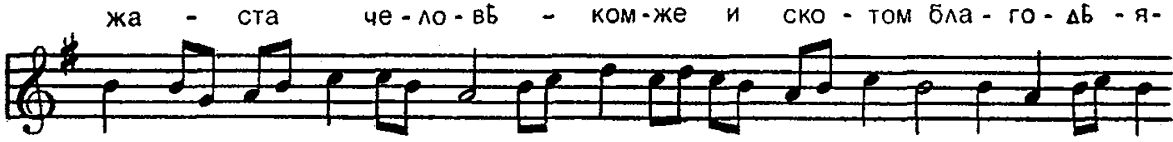
ні- я по- $\Delta a-e$ - те $\Delta a$ во всем по-слу-шли-ви бы - во-

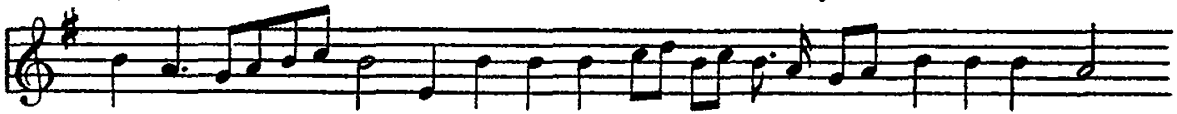

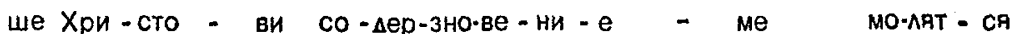

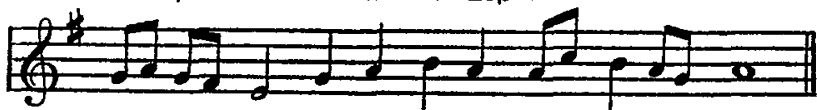

- 4 - wax Ha . . - whx

B)

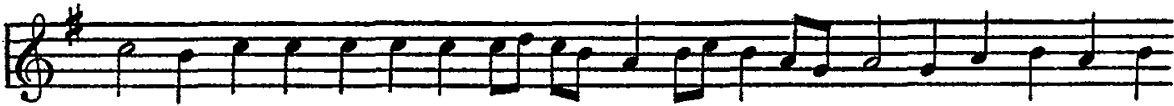

Тре-тыи Аеньвоскресл е-си Хри-сте из гро -

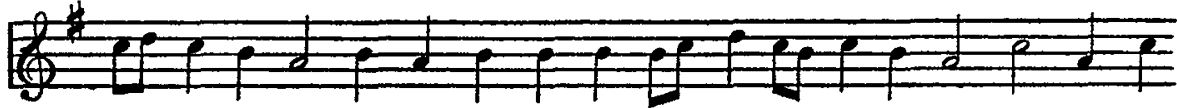

- ca - ho co-вос-кре-ch пра- от. 4 -

Ha-we.ro tbM-жe TA

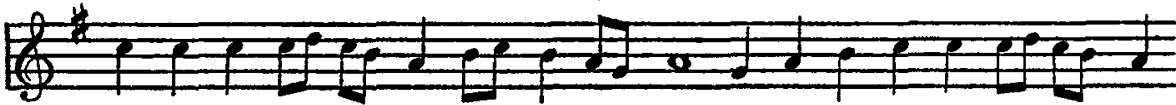

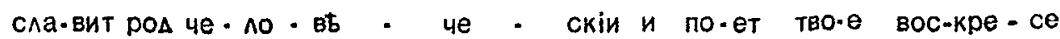

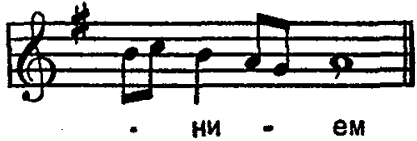

r)

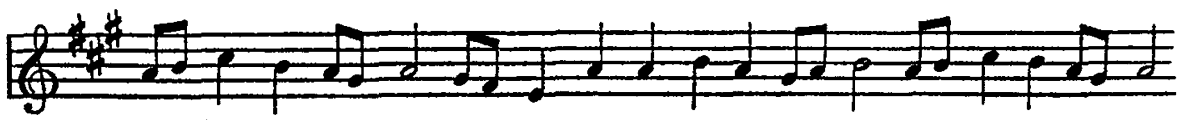
He - Ha- $4 a-e-M a-q$ жи-Ти-я ра $-\Delta и$ и
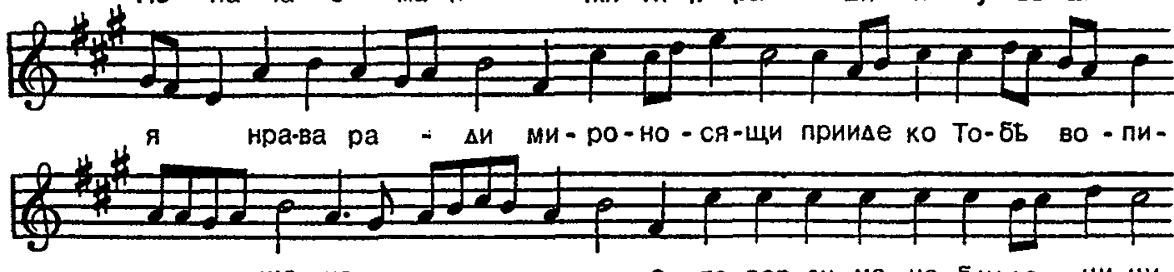

10. He He

o- то-вер-зи ме-не блу-де - ни-4у 

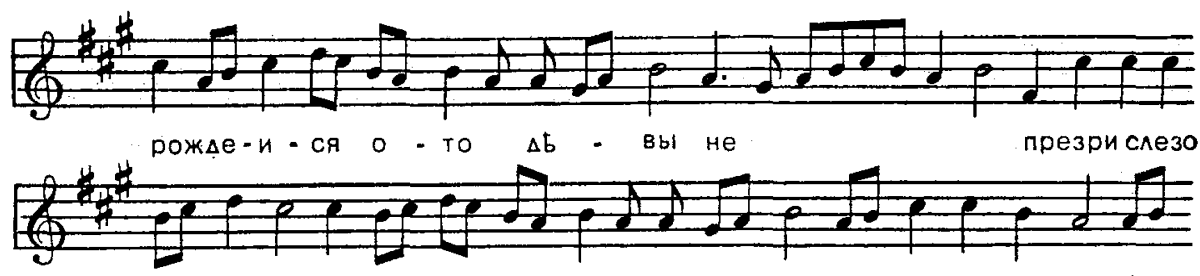

мо-и - хо ра- $о$ - сти ан- ге - $о$ - мо но при-и -ми мя ка-

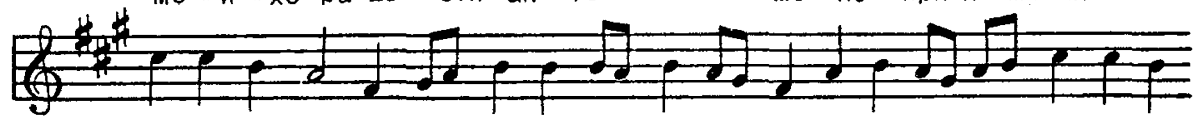

ю-цу - ю-ся e- - - же не о-то-ри - ну со-гре-ше-му (ти) го-спо-

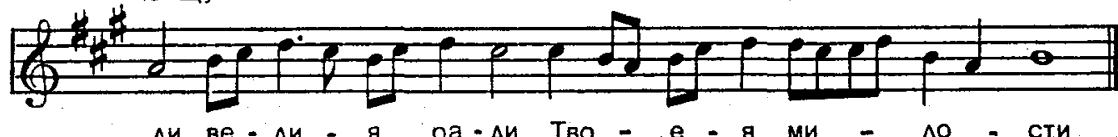

$\Delta и$ ве-ли - я ра- $\Delta и$ Тво - е - м ми - 10 - сти

$\Delta)$
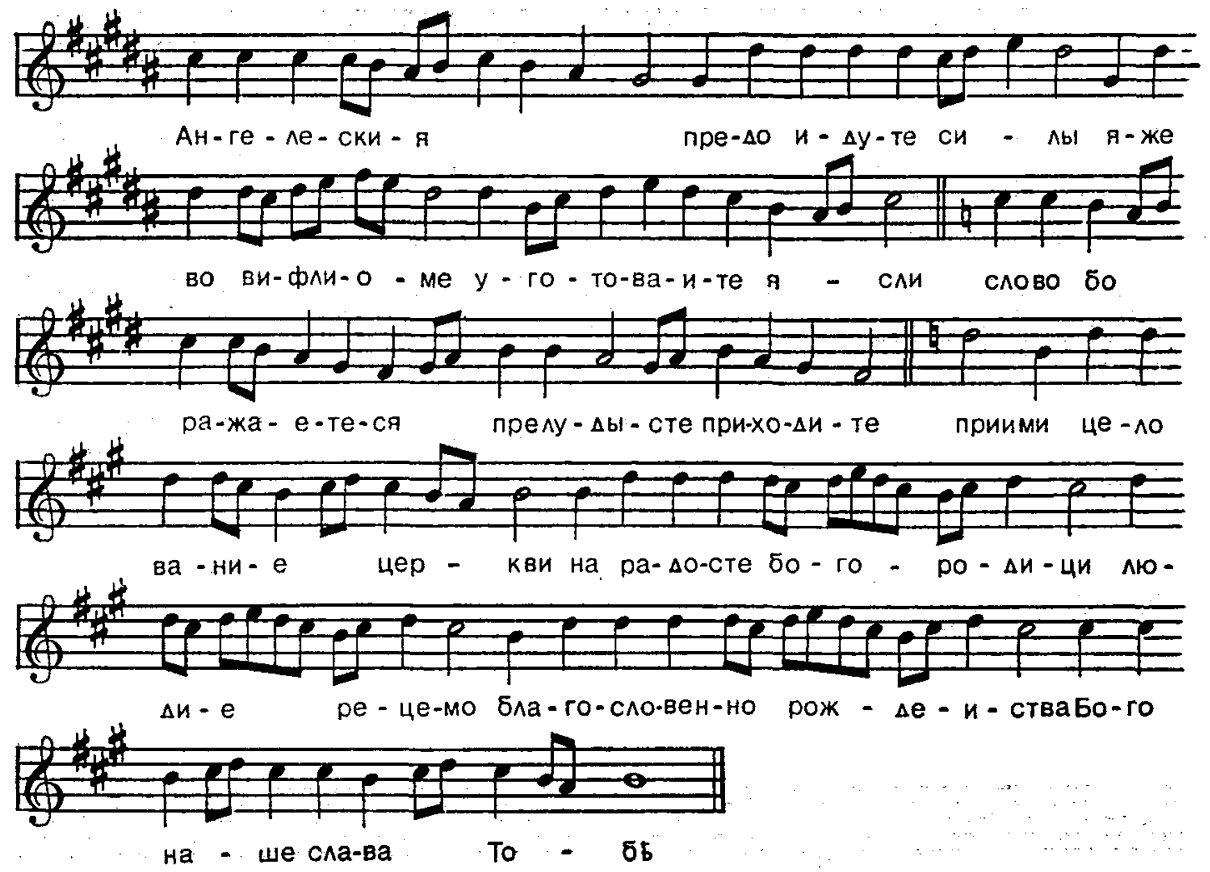

raac 7

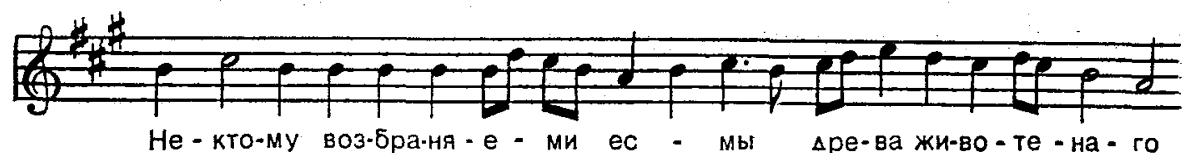

$6 / 3453$ 

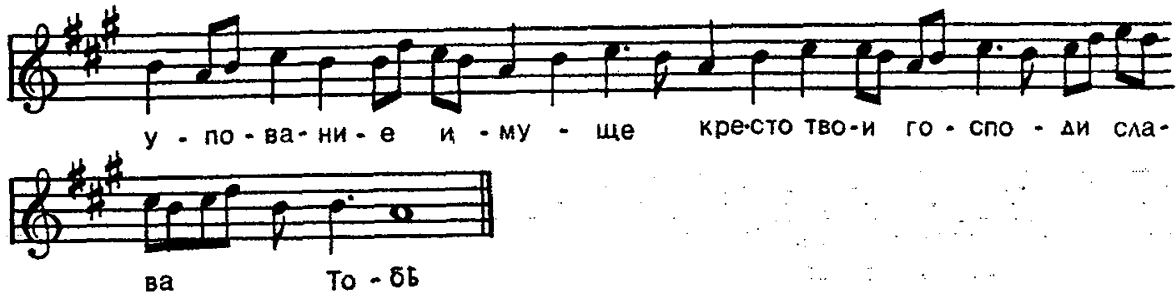

\section{Taac 8}

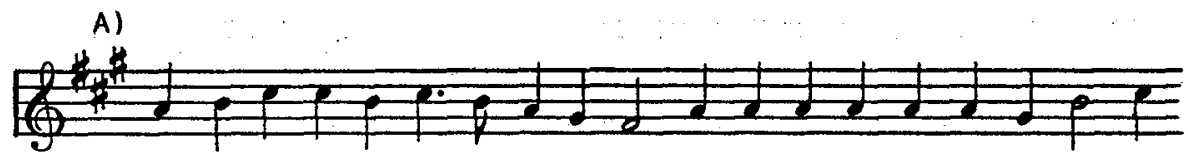

o пре-сла-ве- но-е

чу - $\Delta$ жи-во-Тво-ря -И са-

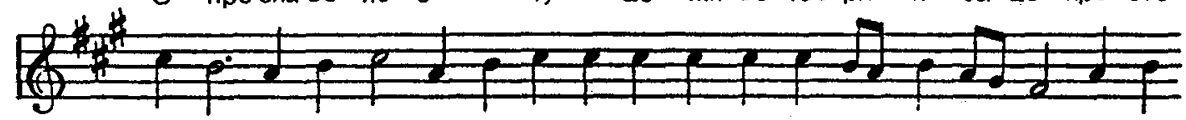

пресвя-ты - и на вы-со-ту воз-Ави-жен я- вля-ет-ся Анесьи сла.

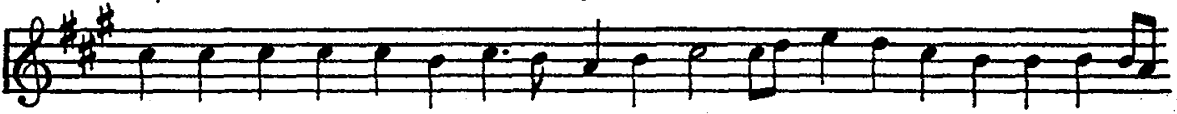

Во- САО-ват ве-

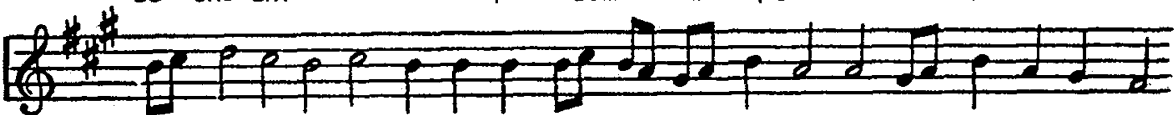

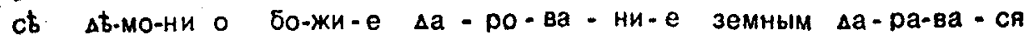
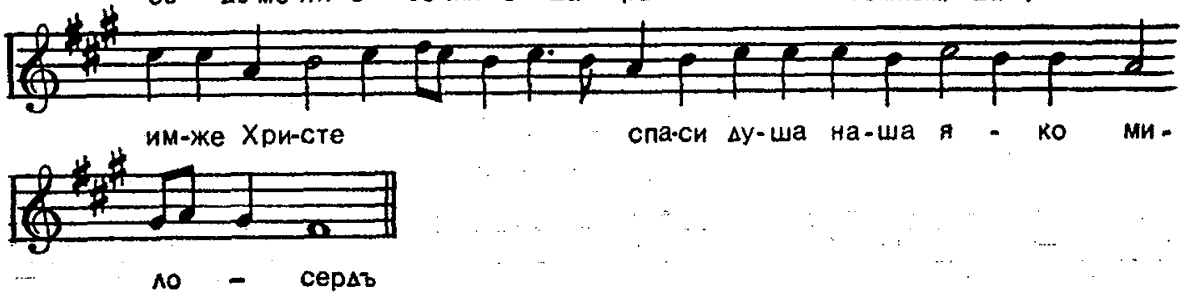

спа.си $у$-ша на-ша я - ко ми-

B)

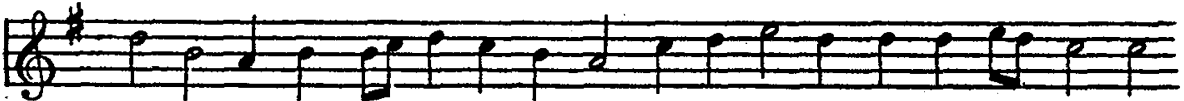

Чтовы на-ре - че-мо свя-ти - и хе - ру-вьм ии я - ко на вас

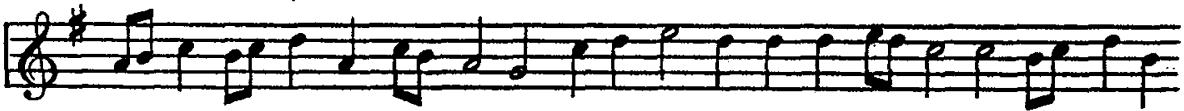
по-чи-ло е-сте Хри-сто-со се - ра-фем ли я-ко вы-ку про-слави

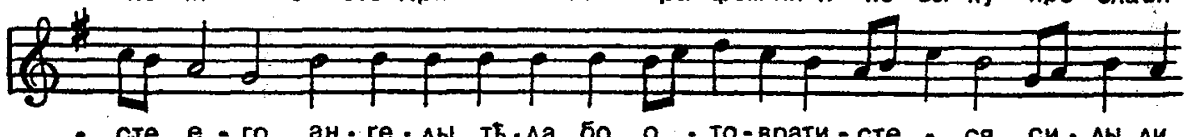



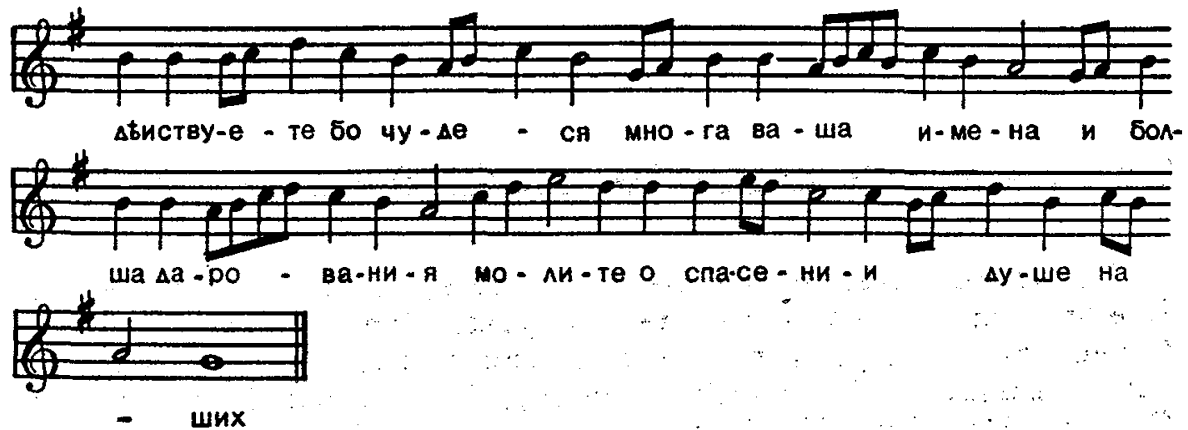